FEDERAL RESERVE BANK OF SAN FRANCISCO

WORKING PAPER SERIES

\title{
Central Bank Credibility During COVID-19: Evidence from Japan
}

\author{
Jens H. E. Christensen \\ Federal Reserve Bank of San Francisco \\ Mark M. Spiegel \\ Federal Reserve Bank of San Francisco
}

August 2022

Working Paper 2021-24

https://www.frbsf.org/economic-research/publications/working-papers/2021/24/

\section{Suggested citation:}

Christensen, Jens H. E., Mark M. Spiegel. 2022 "Central Bank Credibility During COVID-19: Evidence from Japan," Federal Reserve Bank of San Francisco Working Paper 2021-24. https://doi.org/10.24148/wp2021-24

The views in this paper are solely the responsibility of the authors and should not be interpreted as reflecting the views of the Federal Reserve Bank of San Francisco or the Board of Governors of the Federal Reserve System. 


\title{
Central Bank Credibility During COVID-19: Evidence from Japan
}

\author{
Jens H. E. Christensen \\ and \\ Mark M. Spiegel
}

\begin{abstract}
Japanese realized and expected inflation has been below the Bank of Japan's two percent target for many years. We examine the impact of announcements of expansionary monetary and fiscal policy under COVID-19 on inflation expectations from an arbitrage-free term structure model of nominal and real yields. We find that both types of policies failed to lift inflation expectations, which instead declined notably over the pandemic period and are projected to only slowly revert back to Bank of Japan target levels. Our results therefore illustrate the challenges faced in raising well-anchored low inflation expectations.
\end{abstract}

JEL Classification: C32, E43, E52, G12, G17

Keywords: affine arbitrage-free term structure model, unconventional monetary policy, deflation risk, deflation protection, fiscal policy

Christensen: Federal Reserve Bank of San Francisco; Email: Jens.Christensen@sf.frb.org. Spiegel: Federal Reserve Bank of San Francisco; Email: Mark.Spiegel@sf.frb.org. This paper was presented as a keynote address at the 3rd Annual Financial Economics Meeting at the ESSCA School of Management, whose participants are thanked for helpful comments. Helpful comments were also received from participants in the ADBI conference on COVID-19 and Central Banking in Asia and the Pacific, the ICEA INFLATION Conference - 7th conference in the After the Pandemic series, the JFA-PBFJ Special Issue Conference, the Financial Markets and Corporate Governance Conference 2022, and the Inflation and Deflation in Asia Conference for helpful comments, including our discussants Alex Kurov, Etsuro Shioji, and Pierre Siklos, and Naoyuki Yoshino. Furthermore, we thank Gus Kmetz for excellent research assistance. The views in this paper are solely the responsibility of the authors and should not be interpreted as reflecting the views of the Federal Reserve Bank of San Francisco or the Federal Reserve System.

This version: August 2, 2022. 


\section{Introduction}

Japanese inflation has remained far below the Bank of Japan's (BOJ) two percent target on average since its announcement in 2013. As shown in Figure 1, except for a brief period of enthusiasm following the reforms of former Prime Minister Shinzo Abe in 2014 and early 2015, realized inflation has averaged well below 1 percent, with extensive periods spent below zero as well. ${ }^{1}$ This experience has likely weighed on inflation expectations. The literature has long associated anchoring long-term inflation expectations at central bank target values as a key requirement for the conduct of successful monetary policy. For example, Goodfriend (2007) associates the success the Federal Reserve had in mitigating the 2001 U.S. downturn to the fact that inflation expectations were well-anchored around the Federal Reserve's implicit two percent target at the time. ${ }^{2}$

Despite the long duration of the formal two percent target, Japanese inflation expectations have remained around one percent, as indicated by consensus forecasts also shown in the figure. The discrepancy between the two percent inflation target and realized inflation appears to have anchored Japanese long-term inflation expectations at levels far below the two percent target. These low inflation expectations were likely further depressed following the onset of the COVID-19 pandemic. The pandemic, and associated shutdowns adopted to combat the virus, disrupted economic activity and led to volatility in global financial markets. The BOJ responded to the turmoil with a number of monetary policy easings, including both policies designed to lower interest rates and policies aimed at easing financial conditions, such as those designed to support commercial paper and encourage bank lending. Fiscal policy also responded aggressively. Beginning in February 2020, the Japanese government introduced a series of emergency response packages and other stimulus measures designed to address the crisis.

The literature has expressed skepticism about the ability of monetary policy to raise inflation after an extended period of falling short of the inflation target. For example, Ehrmann (2015) shows for a number of inflation targeting (IT) countries that inflation expectations can lose their anchor after a prolonged period of falling below the inflation target. Moreover, he notes that Japan is unique due to its relatively prolonged period below its current two percent target. His results show that Japanese inflation expectations are more backward-looking and sticky than other IT countries in his sample due to its prolonged experience of missing its inflation target. Christensen and Spiegel (2021) examine a number of pre-COVID monetary policy announcements associated with the reforms pursued under then Prime Minister Shinzo Abe beginning in 2013 and also find that they were generally unsuccessful in raising inflation expectations.

\footnotetext{
${ }^{1}$ Yoshino et al. (2017) note that the elevated inflation rates following the Abenomics reforms also reflected the increased global oil prices, with inflation in Japan following oil prices downward after their 2014 spike.

${ }^{2}$ The Federal Open Market Committee (FOMC) did not formally adopt its current two percent target until January 2012.
} 


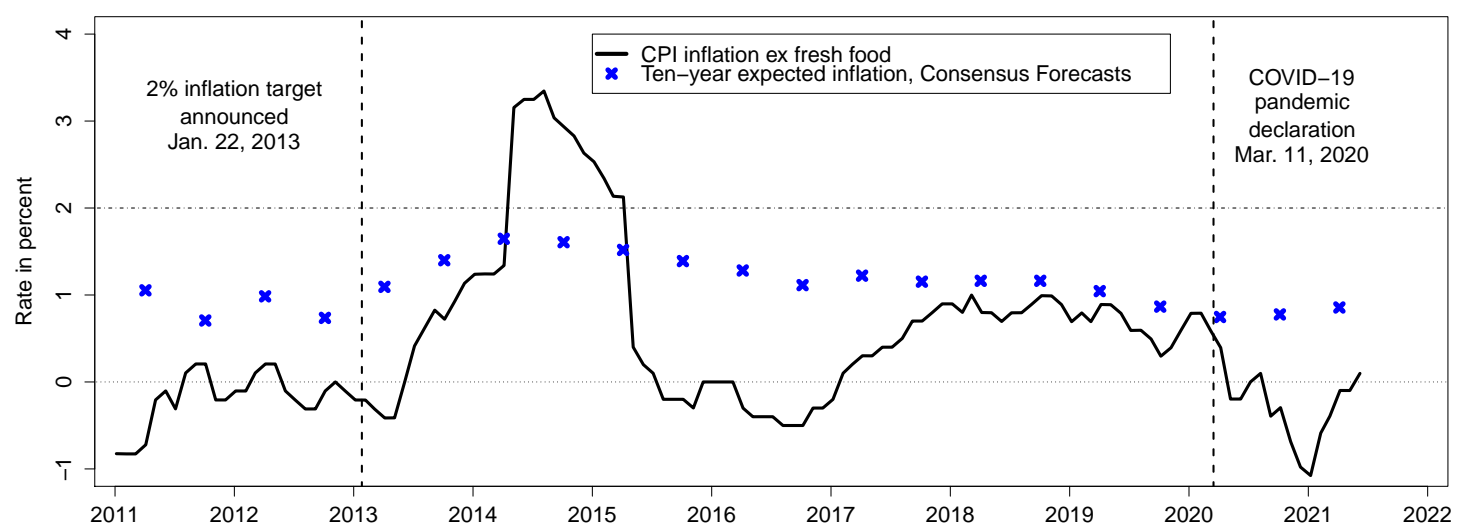

Figure 1: Japanese CPI Inflation ex Fresh Food and Survey Inflation Forecasts

In contrast, one might think that the efficacy of fiscal policy would actually be elevated. A number of studies, e.g., Boubaker (2018) and Ramey and Zubairy (2018), have found that the government spending multiplier for economic activity can be quite high when interest rates are at the ELB, as was the case for Japan under COVID-19. However, in more recent work, Bianchi-Vimercati et al. (2021) demonstrate that the efficacy of the fiscal policy at the ELB can be dependent on the sophistication of economic agents, and in particular may diminish if agents become less rational in their thinking. Of course, the implications for inflation expectations may be quite different. However, one would think that if expansionary fiscal policy were successful at elevating economic activity, it would likely lead to tighter labor market conditions and eventually have an impact on inflation and inflation expectations as well. Moreover, the sheer size of the COVID-19 packages in total, combined with Japan's high debt-to-GDP ratio, raised speculation that they would be associated with greater monetary expansion in the form of elevated central bank purchases of Japanese government bonds.

In this paper, we examine the responses of long-term inflation expectations to recent BOJ monetary policy announcements during the pandemic through a high-frequency event study framework. In particular, we analyze the information reflected in the prices of inflationindexed Japanese government bonds using the arbitrage-free term structure model of Japanese nominal and real yields developed in Christensen and Spiegel (2021) during the onset of the COVID-19 panemdic. Given its relative exogeneity to prevailing economic conditions, the COVID-19 crisis provides a unique opportunity to examine the relative efficacy of countercyclical monetary and fiscal policy to raise inflation expectations when they have been anchored by extended experiences of very low or negative rates of inflation.

To examine the efficacy of Japanese policy interventions under COVID-19, we employ a Gaussian model of Japanese nominal and real government bond yields using methods similar 
to those of, e.g., Abrahams et al. (2016) and D'Amico et al. (2018). ${ }^{3}$ Importantly, our analysis accounts for the value of the deflation protection option embedded in Japanese inflationindexed bond contracts since 2013, using an adaptation of the approach of Christensen et al. (2012). As in that study of inflation-protected U.S. treasuries, these bonds implicitly offer "deflation protection," in the form of paying off the original nominal principal at maturity when deflation has occurred since issuance. These enhancements are particularly important over our sample period, which contains low and often negative Japanese inflation. Our model allows us to identify bond investors' underlying inflation expectations, as in Christensen et al. (2010), and hence to account for inflation risk premia. To obtain the appropriate persistence of the dynamic factors in the model, we follow Kim and Orphanides (2012) and incorporate long-term forecasts of inflation from surveys of professional forecasters.

Our results indicate an unprecedented spike in the deflation risk premium consistent with the spell of deflation experienced in Japan at the onset of the pandemic. This implies an equally dramatic decline in option-adjusted break-even inflation (BEI) rates. This decline primarily reflects declines in the inflation risk premium, although investors' long-term inflation expectations also were negatively affected by this shock. Indeed, our results suggest that investors' ten-year inflation expectations have declined 0.8 percent since February 2020. However, model projections suggest that the ten-year expected inflation will revert back close to 1 percent within five years.

We then apply our model to a high-frequency event study of the impact of announcements of counter-cyclical monetary and fiscal policy. ${ }^{4}$ Using daily data allows for the decomposition of long-term yield changes into changes to expected inflation and associated risk premia. ${ }^{5}$

We identify five important announcements of BOJ monetary and credit responses to the COVID-19 crisis. These include reductions in the policy rate, increases in purchases of government treasuries and commercial paper, forward guidance concerning purchases of exchange traded funds (ETFs) and Japanese real-estate investment trusts (J-REITs), announced between March 16, 2020, and March 19, 2021. On the fiscal side, we evaluate the implications of the announcements of seven COVID-19 response fiscal packages and emergency measures, between February 13 and December 7, 2020. Overall, the total fiscal stimulus amounted to about $\$ 3$ trillion, or 60 percent of Japanese nominal GDP. ${ }^{6}$ For comparison purposes, we also

\footnotetext{
${ }^{3}$ As our model is Gaussian, it does not respect any lower bounds on nominal yields. This could modestly bias our results over the early portion of our sample when Japanese yields appeared to be constrained by the zero lower bound. However, during the COVID-19 period, Japan had negative nominal rates and the existence of a lower bound on nominal yields is unclear. Our Gaussian dynamics are required to account for the deflation protection enhancement in Japanese inflation-indexed bonds.

${ }^{4}$ Bernhardt et al. (2022) examine the relative importance of COVID-19 related monetary and fiscal policy responses on the performance of U.S. municipal debt markets.

${ }^{5}$ Gagnon et al. (2011), Christensen and Rudebusch (2012), and Bauer and Rudebusch (2014) provide term structure model decompositions of the U.S. experience with unconventional monetary policies, while Christensen and Krogstrup (2019) use a similar approach to evaluate the Swiss experience with unconventional reserve expansions.

${ }^{6}$ The effective amount of stimulus is likely to be smaller than the headline number. Gornostay and Sarsenbayev (2021) make adjustments to compare the Japanese packages to the fiscal stimulus of other G7 countries
} 
consider the implications of announcements concerning the imposition or lifting of restrictions on economic activity in response to developments associated with the pandemic. These are described in detail, along with designations of individual event dates, below.

Our results indicate that inflation expectations failed to rise on any of the monetary and fiscal announcement trading days studied. We also find long-term inflation expectations largely unresponsive at the daily frequency to news concerning the imposition or lifting of restrictions associated with the progression of the pandemic. Taken together, our results indicate that, if anything, government efforts through both monetary and fiscal expansion raised rather than lowered investor concerns about Japanese deflation, and in particular failed to make any progress in moving long-term inflation expectations towards the BOJ's two percent target. As such, they illustrate the challenges facing policymakers when longterm inflation expectations are anchored far below the announced policy target.

The remainder of this paper is structured as follows. Section 2 describes the data. Section 3 details our benchmark model used to decompose the nominal and real bond yields into underlying expectations and residual risk premia. It then estimates our model and summarizes its results. Section 4 examines the implications of the global pandemic on the long-term inflation expectations of investors in the Japanese government bond market. Section 5 conducts event studies using our estimated benchmark model to evaluate the impact of monetary and fiscal policy actions aimed at stabilizing the Japanese economy in the face of the COVID-19 crisis. We also examine market responses to more general policy responses aimed at combatting the virus. Lastly, concluding comments are provided in Section 6.

\section{Japanese Government Bond Data}

The Japanese government bond market is large and liquid by international standards. As of December 2020, the total outstanding notional amount of marketable bonds issued by the government of Japan was 1,212.5 trillion yen, of which close to 1 percent represented inflationindexed bonds. ${ }^{7}$ In total, Japanese government debt reached $266 \%$ of Japanese nominal GDP in 2020 , far above the level of any other major industrialized country. ${ }^{8}$

\subsection{Nominal Bonds}

We follow Christensen and Spiegel (2021) and extend the Japanese nominal government bond yield series in Kim and Singleton (2012), which originally ended in March 2008, with Japanese nominal government zero-coupon yields to June 2021. ${ }^{9}$ This data set contains six maturities: six-month yields and one-, two-, four-, seven-, and ten-year yields, with all yields being and report them to be equal to $16.3 \%$ of 2020 nominal GDP, which still represents an unprecedented amount of stimulus in peacetime.

${ }^{7}$ Source: https://www.mof.go.jp/english/jgbs/publication/newsletter/jgb2021_02e.pdf

${ }^{8}$ Source: tradingeconomics.com/japan/government-debt-to-gdp

${ }^{9}$ Extension data is downloaded from Bloomberg, as in Christensen and Rudebusch (2015). 


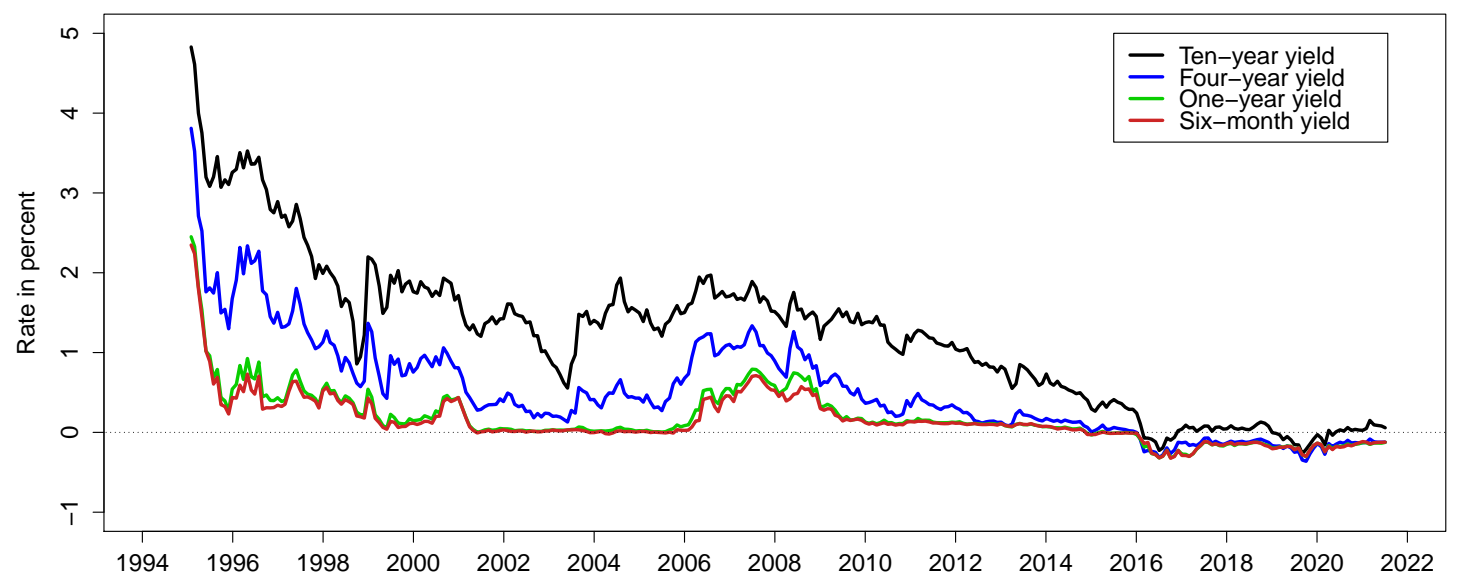

Figure 2: Japanese Nominal Government Bond Yields

Illustration of the Japanese nominal government zero-coupon bond yields with maturities of six months, one year, four years, and ten years. The data series are monthly covering the period from January 31 , 1995, to June 30, 2021.

continuously compounded and available at daily frequency. We examine the data at daily and monthly frequencies, with monthly data measured through end-of-month values.

Figure 2 shows the persistent drop in yields since the mid-1990s for four of our nominal yields. We also observe a persistent decline in the yield spreads. The spread between the tenand one-year yield was larger than 200 basis points at the start of the sample and less than 25 basis points at the end of the sample. We follow Kim and Singleton (2012), who find that a two-factor model is adequate to fit their data, and use a two-factor model for the nominal yields. ${ }^{10}$

\subsection{Real Bonds}

The Japanese government has issued inflation-indexed bonds-known as JGBi-since the spring of 2004. These are all ten-year bonds, which were issued in two separate periods. From March 2004 until June 2008, a total of 16 bonds were issued with a nearly quarterly frequency. The program was then temporarily halted in the aftermath of the global financial crisis. However, new inflation-indexed bonds have been issued roughly once a year since the fall of 2013. These are government bonds whose principal amount fluctuates in proportion with the consumer price index (CPI) excluding fresh food.

This latter period of issuance included the deflation protection enhancement noted in

\footnotetext{
${ }^{10}$ While the BOJ's purchases of close to 45 percent of all outstanding JGBs by the end of our sample raises the possibility of illiquidity in this market, both Kurosaki et al. (2015) and Sakiyama and Kobayashi (2018) find no evidence of market impairment during our sample period.
} 


\begin{tabular}{|c|c|c|c|c|c|}
\hline \multirow{2}{*}{ JGBi (coupon, maturity) } & \multirow{2}{*}{$\begin{array}{l}\text { No. } \\
\text { obs. }\end{array}$} & \multicolumn{2}{|c|}{ Issuance } & \multirow{2}{*}{$\begin{array}{l}\text { Number of } \\
\text { auctions }\end{array}$} & \multirow{2}{*}{$\begin{array}{c}\text { Total notional } \\
\text { amount }\end{array}$} \\
\hline & & Date & amount & & \\
\hline (1) $1.2 \% 3 / 10 / 2014$ & 86 & $3 / 10 / 2004$ & 100 & 1 & 100 \\
\hline (2) $1.1 \%$ 6/10/2014 & 88 & $6 / 10 / 2004$ & 300 & 1 & 300 \\
\hline (3) $0.5 \% \quad 12 / 10 / 2014$ & 98 & $12 / 10 / 2004$ & 500 & 1 & 500 \\
\hline (4) $0.5 \% 6 / 10 / 2015$ & 100 & $6 / 10 / 2005$ & 500 & 1 & 500 \\
\hline (5) $0.8 \% 9 / 10 / 2015$ & 96 & $9 / 12 / 2005$ & 500 & 1 & 500 \\
\hline (6) $0.8 \% 12 / 10 / 2015$ & 90 & $12 / 12 / 2005$ & 500 & 1 & 500 \\
\hline (7) $0.8 \% 3 / 10 / 2016$ & 92 & $3 / 10 / 2006$ & 500 & 1 & 500 \\
\hline (8) $1 \%$ 6/10/2016 & 87 & $6 / 12 / 2006$ & 500 & 2 & 1000 \\
\hline (9) $1.1 \% 9 / 10 / 2016$ & 89 & $10 / 11 / 2006$ & 500 & 1 & 500 \\
\hline (10) $1.1 \% 12 / 10 / 2016$ & 88 & $12 / 12 / 2006$ & 500 & 2 & 1000 \\
\hline (11) $1.2 \% 3 / 10 / 2017$ & 84 & $4 / 10 / 2007$ & 500 & 1 & 500 \\
\hline (12) $1.2 \% 6 / 10 / 2017$ & 91 & $6 / 12 / 2007$ & 500 & 2 & 1000 \\
\hline (13) $1.3 \% 9 / 10 / 2017$ & 81 & $10 / 10 / 2007$ & 500 & 1 & 500 \\
\hline (14) $1.2 \% \quad 12 / 10 / 2017$ & 84 & $12 / 11 / 2007$ & 500 & 2 & 1000 \\
\hline (15) $1.4 \% 3 / 10 / 2018$ & 80 & $4 / 10 / 2008$ & 500 & 1 & 500 \\
\hline (16) $1.4 \% 6 / 10 / 2018$ & 80 & $6 / 10 / 2008$ & 500 & 2 & 1000 \\
\hline (17) $0.1 \% 9 / 10 / 2023$ & 93 & $10 / 10 / 2013$ & 300 & 2 & 600 \\
\hline (18) $0.1 \% 3 / 10 / 2024$ & 85 & $4 / 10 / 2014$ & 400 & 2 & 800 \\
\hline (19) $0.1 \%$ 9/10/2024 & 79 & $10 / 10 / 2014$ & 500 & 2 & 1000 \\
\hline (20) $0.1 \% 3 / 10 / 2025$ & 74 & $5 / 12 / 2015$ & 500 & 4 & 2000 \\
\hline (21) $0.1 \% 3 / 10 / 2026$ & 61 & $4 / 14 / 2016$ & 400 & 4 & 1600 \\
\hline (22) $0.1 \% 3 / 10 / 2027$ & 51 & $4 / 13 / 2017$ & 400 & 4 & 1600 \\
\hline (23) $0.1 \% 3 / 10 / 2028$ & 38 & $5 / 11 / 2018$ & 400 & 4 & 1600 \\
\hline (24) $0.1 \% 3 / 10 / 2029$ & 26 & $5 / 13 / 2019$ & 400 & 4 & 1600 \\
\hline (25) $0.2 \% 3 / 10 / 2030$ & 14 & $5 / 11 / 2020$ & 200 & 4 & 800 \\
\hline (26) $0.005 \% 3 / 10 / 2031$ & 2 & $5 / 18 / 2021$ & 200 & 1 & 200 \\
\hline
\end{tabular}

Table 1: Sample of Japanese Real Government Bonds

The table reports the characteristics, first issuance date and amount, the total number of auctions, and total amount issued in billions of Japanese yen for the sample of Japanese inflation-indexed government bonds (JGBi). Also reported are the number of monthly observation dates for each bond during the sample period from January 31, 2005, to June 30, 2021.

the introduction. These bonds are guaranteed to pay off at par at maturity, even if there was net deflation between the issuance and maturity dates, effectively embedding a deflation protection option into the bond contract. ${ }^{11}$ Table 1 contains the contractual details of all 26 JGBi's in our sample as well as their individual number of monthly observations.

The distribution of individual JGBi's for each date in our sample is illustrated in Figure 3(a). Each bond's trajectory over time in terms of remaining years to maturity is represented by a diagonal solid black line that starts at its date of issuance with a value equal to its original maturity and ends at zero on its maturity date. The two waves of issuances of JGBi's are clearly visible.

\footnotetext{
${ }^{11}$ See https://www.mof.go.jp/english/jgbs/topics/bond/10year_inflation/index.htm
} 


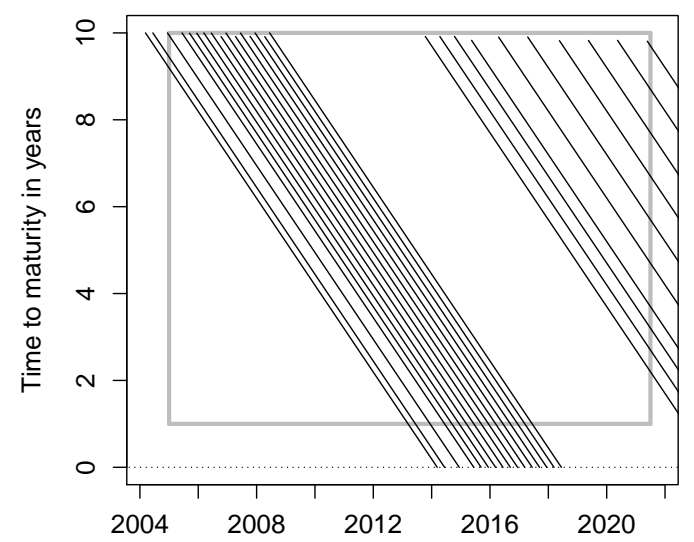

(a) Distribution of inflation-indexed bonds

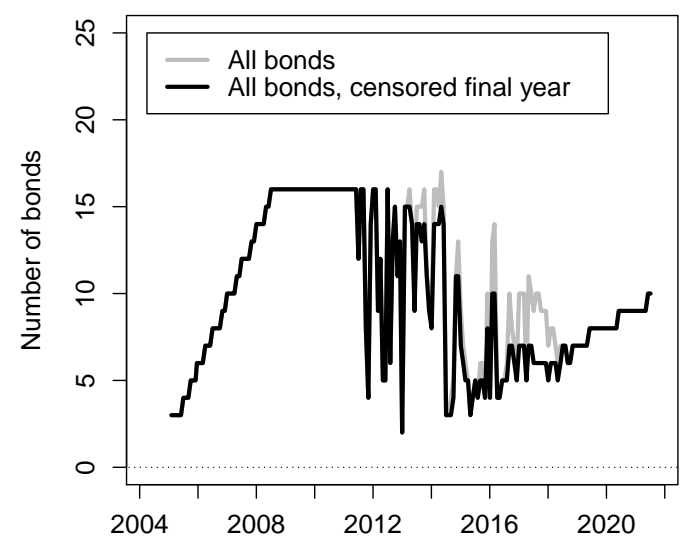

(b) Number of inflation-indexed bonds

Figure 3: Real Japanese Government Bond Sample

Panel (a) shows the maturity distribution of available Japanese inflation-indexed government bonds (JGBi) on any given date. The solid grey rectangle indicates the sample used in our empirical analysis. The sample is restricted to start on January 31, 2005, and limited to inflation-indexed bond prices with more than one year remaining to maturity. Panel (b) reports the number of outstanding inflationindexed bonds available at a given point in time for various samples.

The solid grey rectangle in Figure 3(a) indicates the sub-sample of bonds used in our empirical analysis. The sample is restricted to start on January 31, 2005, and limited to inflation-indexed bond prices with more than one year remaining to maturity.

Figure 3(b) shows the distribution across time of the number of JGBi's included in the sample. Our sample starts with three bonds and increases to sixteen bonds by 2008. The number of bonds available then gradually declined beginning in 2011, as bonds from the first wave of issuances started to mature. However, since 2018, the number of bonds have been gradually increasing due to the second wave of issuance. At the end of our sample there are ten bonds. The number of inflation-indexed bonds $n_{R}(t)$ combined with the time variation in the cross-sectional dispersion in the maturity dimension observed in Figure 3(a) provides the identification of the real factors in our model. ${ }^{12}$

Figure 4 shows the yields to maturity for all 26 Japanese inflation-indexed bonds. We see notable changes in the level and slope of the Japanese real yield curve, which motivates our choice to model the inflation-indexed data with two real yield factors. Note also that the series for individual bonds show gaps as the bonds approach maturity. Our use of all available bond price information in combination with the Kalman filter is designed to handle such data gaps.

\footnotetext{
${ }^{12}$ Finlay and Wende (2012) represent an early example of analysis like ours based on prices from a limited number of Australian inflation-indexed bonds.
} 


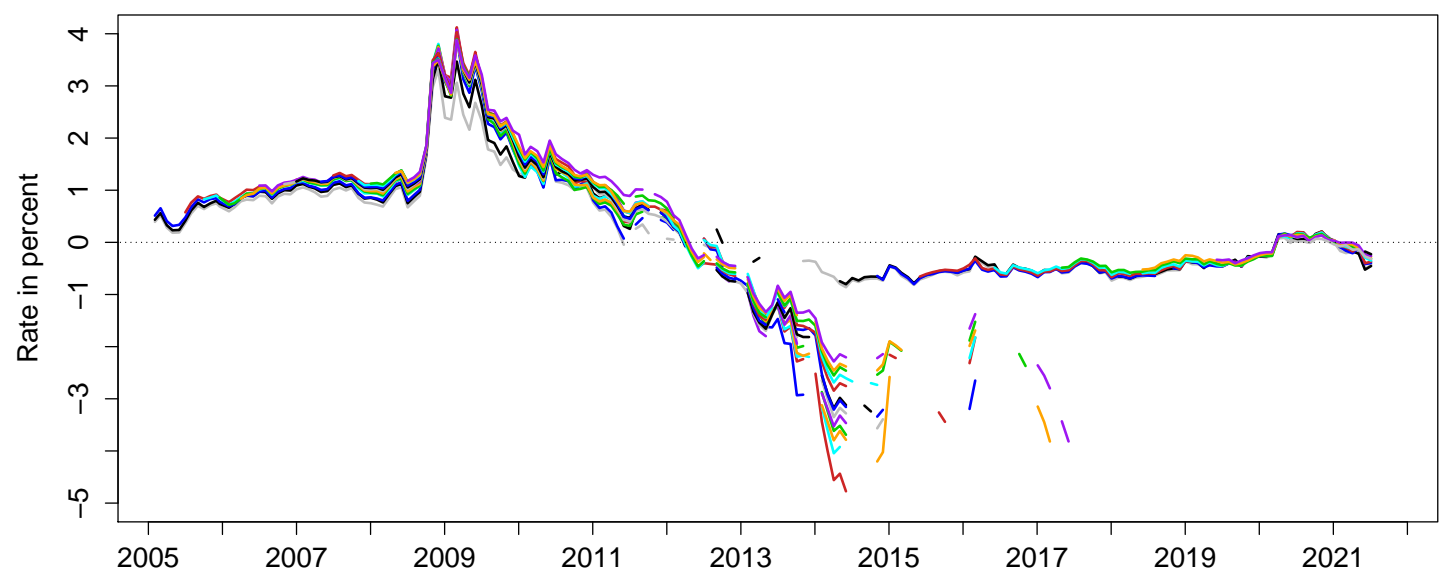

Figure 4: Yield to Maturity of Japanese Real Government Bonds

Illustration of the yield to maturity of the Japanese inflation-indexed bonds considered in this paper, which are subject to two sample choices: (1) sample limited to the period from January 31, 2005, to June 30,2021 ; (2) censoring of a bond's price when it has less than one year to maturity.

\section{Model Estimation and Results}

In this section, we first detail our benchmark model, taken from Christensen and Spiegel (2021), which we use to decompose the nominal and real bond yields into underlying expectations and residual risk premia, while evaluating the value of the inflation-indexed bond deflation enhancement. We then describe our identification restrictions, estimate the model, and summarize our results.

\subsection{An Arbitrage-Free Model of Nominal and Real Yields}

Our joint model of nominal and real yields has a state vector denoted by $X_{t}=\left(L_{t}^{N}, S_{t}^{N}, L_{t}^{R}, S_{t}^{R}\right)$, where $\left(L_{t}^{N}, S_{t}^{N}\right)$ represent level and slope factors in the nominal yield curve, while $\left(L_{t}^{R}, S_{t}^{R}\right)$ represent separate level and slope factors in the real yield curve. ${ }^{13}$ The instantaneous nominal and real risk-free rates are defined as

$$
r_{t}^{j}=L_{t}^{j}+S_{t}^{j}, \quad j=N, R
$$

To obtain a Nelson and Siegel (1987) factor loading structure in the yield functions, the risk-neutral, or $\mathbb{Q}$, dynamics of the state variables must be assumed to be given by the

\footnotetext{
${ }^{13}$ Chernov and Mueller (2012) provide evidence of a hidden factor in the U.S. nominal yield curve that is observable from real yields and inflation expectations. Our joint model accommodates this stylized fact via the factors $\left(L_{t}^{R}, S_{t}^{R}\right)$.
} 
following system of stochastic differential equations:

$$
\left(\begin{array}{l}
d L_{t}^{N} \\
d S_{t}^{N} \\
d L_{t}^{R} \\
d S_{t}^{R}
\end{array}\right)=\left(\begin{array}{cccc}
0 & 0 & 0 & 0 \\
0 & -\lambda^{N} & 0 & 0 \\
0 & 0 & 0 & 0 \\
0 & 0 & 0 & -\lambda^{R}
\end{array}\right)\left(\begin{array}{c}
L_{t}^{N} \\
S_{t}^{N} \\
L_{t}^{R} \\
S_{t}^{R}
\end{array}\right) d t+\left(\begin{array}{cccc}
\sigma_{11} & 0 & 0 & 0 \\
\sigma_{21} & \sigma_{22} & 0 & 0 \\
\sigma_{31} & \sigma_{32} & \sigma_{33} & 0 \\
\sigma_{41} & \sigma_{42} & \sigma_{43} & \sigma_{44}
\end{array}\right)\left(\begin{array}{c}
d W_{t}^{L^{N}, \mathbb{Q}} \\
d W_{t}^{S^{N}, \mathbb{Q}} \\
d W_{t}^{L^{R}, \mathbb{Q}} \\
d W_{t}^{S^{R}, \mathbb{Q}}
\end{array}\right) .
$$

Based on this specification of the $\mathbb{Q}$-dynamics, nominal and real zero-coupon bond yields preserve a simplified Nelson and Siegel (1987) factor loading structure:

$$
y_{t}^{j}(\tau)=L_{t}^{j}+\left(\frac{1-e^{-\lambda^{j} \tau}}{\lambda^{j} \tau}\right) S_{t}^{j}-\frac{A^{j}(\tau)}{\tau}, \quad j=N, R,
$$

where the nominal and real yield-adjustment terms are given by

$$
\begin{aligned}
\frac{A^{N}(\tau)}{\tau}= & \frac{\sigma_{11}^{2}}{6} \tau^{2}+\left(\sigma_{21}^{2}+\sigma_{22}^{2}\right)\left[\frac{1}{2\left(\lambda^{N}\right)^{2}}-\frac{1}{\left(\lambda^{N}\right)^{3}} \frac{1-e^{-\lambda^{N} \tau}}{\tau}+\frac{1}{4\left(\lambda^{N}\right)^{3}} \frac{1-e^{-2 \lambda^{N} \tau}}{\tau}\right] \\
& +\sigma_{11} \sigma_{21}\left[\frac{1}{2 \lambda^{N}} \tau+\frac{1}{\left(\lambda^{N}\right)^{2}} e^{-\lambda^{N} \tau}-\frac{1}{\left(\lambda^{N}\right)^{3}} \frac{1-e^{-\lambda^{N} \tau}}{\tau}\right] \\
\frac{A^{R}(\tau)}{\tau}= & \frac{\sigma_{31}^{2}+\sigma_{32}^{2}+\sigma_{33}^{2}}{6} \tau^{2} \\
& +\left(\sigma_{41}^{2}+\sigma_{42}^{2}+\sigma_{43}^{2}+\sigma_{44}^{2}\right)\left[\frac{1}{2\left(\lambda^{R}\right)^{2}}-\frac{1}{\left(\lambda^{R}\right)^{3}} \frac{1-e^{-\lambda^{R} \tau}}{\tau}+\frac{1}{4\left(\lambda^{R}\right)^{3}} \frac{1-e^{-2 \lambda^{R} \tau}}{\tau}\right] \\
& +\left(\sigma_{31} \sigma_{41}+\sigma_{32} \sigma_{42}+\sigma_{33} \sigma_{43}\right)\left[\frac{1}{2 \lambda^{R}} \tau+\frac{1}{\left(\lambda^{R}\right)^{2}} e^{-\lambda^{R} \tau}-\frac{1}{\left(\lambda^{R}\right)^{3}} \frac{1-e^{-\lambda^{R} \tau}}{\tau}\right] .
\end{aligned}
$$

To implement our model empirically, we need to specify the risk premia that connect these factor dynamics under the $\mathbb{Q}$-measure to the dynamics under the real-world $\mathbb{P}$-measure. It is important to note that there are no restrictions on the dynamic drift components under the empirical $\mathbb{P}$-measure beyond the requirement of constant volatility. To facilitate empirical implementation, we use the essentially affine risk premium specification introduced in Duffee (2002). In a Gaussian framework, this specification implies that the risk premia $\Gamma_{t}$ depend on the state variables; that is,

$$
\Gamma_{t}=\gamma^{0}+\gamma^{1} X_{t}
$$

where $\gamma^{0} \in \mathbf{R}^{4}$ and $\gamma^{1} \in \mathbf{R}^{4 \times 4}$ contain unrestricted parameters. Thus, the resulting unrestricted four-factor joint model of nominal and real yields has $\mathbb{P}$-dynamics given by

$$
d X_{t}=K^{\mathbb{P}}\left(\theta^{\mathbb{P}}-X_{t}\right)+\Sigma d W_{t}^{\mathbb{P}}
$$

where $K^{\mathbb{P}}$ is an unrestricted $4 \times 4$ mean-reversion matrix, $\theta^{\mathbb{P}}$ is a $4 \times 1$ vector of mean levels, and $\Sigma$ is a $4 \times 4$ lower triangular volatility matrix.

This is the transition equation in the Kalman filter estimation. Going forward, we follow 
Christensen and Spiegel (2021) and refer to this Gaussian joint four-factor model of nominal and real yields as the $G^{J}(4)$ model and use it as our base model for estimation.

\subsection{Decomposing Bond Yields}

As explained in Christensen and Spiegel (2021), the price of a nominal zero-coupon bond with maturity in $\tau$ years can be written as

$$
P_{t}^{N}(\tau)=P_{t}^{R}(\tau) \times E_{t}^{\mathbb{P}}\left[\frac{\Pi_{t}}{\Pi_{t+\tau}}\right] \times\left(1+\frac{\operatorname{cov}_{t}^{\mathbb{P}}\left[\frac{M_{t+\tau}^{R}}{M_{t}^{R}}, \frac{\Pi_{t}}{\Pi_{t+\tau}}\right]}{E_{t}^{\mathbb{P}}\left[\frac{M_{t+\tau}^{R}}{M_{t}^{R}}\right] \times E_{t}^{\mathbb{P}}\left[\frac{\Pi_{t}}{\Pi_{t+\tau}}\right]}\right),
$$

where $P_{t}^{R}(\tau)$ is the price of a real zero-coupon bond that pays one consumption unit in $\tau$ years, $M_{t}^{R}$ is the real stochastic discount factor, and $\Pi_{t}$ is the price level.

By taking logarithms, this can be converted into

$$
y_{t}^{N}(\tau)=y_{t}^{R}(\tau)+\pi_{t}^{e}(\tau)+\phi_{t}(\tau)
$$

where $y_{t}^{N}(\tau)$ and $y_{t}^{R}(\tau)$ are nominal and real zero-coupon yields as described in the previous section, while the market-implied average rate of inflation expected at time $t$ for the period from $t$ to $t+\tau$ is

$$
\pi_{t}^{e}(\tau)=-\frac{1}{\tau} \ln E_{t}^{\mathbb{P}}\left[\frac{\Pi_{t}}{\Pi_{t+\tau}}\right]=-\frac{1}{\tau} \ln E_{t}^{\mathbb{P}}\left[e^{-\int_{t}^{t+\tau}\left(r_{s}^{N}-r_{s}^{R}\right) d s}\right]
$$

and the associated inflation risk premium for the same time period is

$$
\phi_{t}(\tau)=-\frac{1}{\tau} \ln \left(1+\frac{\operatorname{cov}_{t}^{\mathbb{P}}\left[\frac{M_{t+\tau}^{R}}{M_{t}^{R}}, \frac{\Pi_{t}}{\Pi_{t+\tau}}\right]}{E_{t}^{\mathbb{P}}\left[\frac{M_{t+\tau}^{R}}{M_{t}^{R}}\right] \times E_{t}^{\mathbb{P}}\left[\frac{\Pi_{t}}{\Pi_{t+\tau}}\right]}\right) .
$$

This last equation demonstrates that the inflation risk premium can be positive or negative. It is positive if and only if

$$
\operatorname{cov}_{t}^{\mathbb{P}}\left[\frac{M_{t+\tau}^{R}}{M_{t}^{R}}, \frac{\Pi_{t}}{\Pi_{t+\tau}}\right]<0
$$

That is, the riskiness of nominal bonds relative to real bonds depends on the covariance between the real stochastic discount factor and inflation, and is ultimately determined by investor preferences, as in, for example, Rudebusch and Swanson (2012).

Now, the BEI rate is defined as the difference between nominal and real yields of the same maturity

$$
B E I_{t}(\tau) \equiv y_{t}^{N}(\tau)-y_{t}^{R}(\tau)=\pi_{t}^{e}(\tau)+\phi_{t}(\tau)
$$


Note that it can be decomposed into the sum of expected inflation and the inflation risk premium.

\subsection{Deflation Protection Option Values}

We next evaluate the value of the deflation protection enhancement that has been embedded in Japanese inflation-indexed bonds issued since 2013. As inflation in Japan has averaged close to zero since the inception of deflation protection in 2013, the potential for net deflation over the life of bonds issued after that date has been non-trivial, leaving the deflation protection enhancement likely to be of significant value. It follows that failure to account for the deflation protection enhancement reduces the quality of estimates of BEI from JGB yields.

Consider an inflation-indexed bond issued at time $t_{0}$ with a reference price index value equal to $\Pi_{t_{0}}$. By time $t$, its accrued inflation compensation is $\frac{\Pi_{t}}{\Pi_{t_{0}}}$, which we define as the "inflation index ratio." There are then two mutually exclusive scenarios: First, the net price index change to maturity $T$ could be sufficiently positive that the inflation index ratio is greater than one. Given this outcome, the bond will pay off its inflation-adjusted principal $\frac{\Pi_{T}}{\Pi_{t_{0}}}$ at maturity.

Alternatively, the net price index change between $t$ and $T$ may be insufficient, leaving the net change less than one. Given that outcome, the deflation protection option will be in the money, as the inflation-indexed bond returns its original principal. The value of the deflation protection option, $D O V_{t}$, is then given by ${ }^{14}$

$$
\operatorname{DOV}_{t}\left(\frac{\Pi_{t}}{\Pi_{t_{0}}}\right)=\left[E_{t}^{\mathbb{Q}}\left[e^{-\int_{t}^{T} r_{s}^{N} d s} \mathbf{1}_{\left\{\frac{\Pi_{T}}{\Pi_{t}} \leq \frac{\Pi_{t_{0}}}{\Pi_{t}}\right\}}\right]-E_{t}^{\mathbb{Q}}\left[e^{-\int_{t}^{T} r_{s}^{R} d s} \mathbf{1}_{\left\{\frac{\Pi_{T}}{\Pi_{t}} \leq \frac{\Pi_{t_{0}}}{\Pi_{t}}\right\}}\right]\right] .
$$

The option value will be lower when accrued inflation compensation is larger, as it is less likely that the net price index change over the bond's remaining life will be sufficiently low (or negative) to bring the option back into the money. Moreover, when accrued inflation is larger, the option value is lower the shorter is the remaining time to maturity, as the probability of bringing the option back into the money at maturity is reduced.

\subsection{Model Estimation and Econometric Identification}

We estimate the model using a conventional likelihood-based approach, where we extract latent pricing factors from our observed data, nominal zero-coupon yields and inflation-indexed mid-market yields to maturity. The functional form for nominal yields is specified as affine and provided in equation (1), whereas the expression for the yield to maturity $\hat{y}_{t}^{R}$ of an inflation-indexed bond with maturity at $T$ that pays an annual coupon $C$ semi-annually is given by the solution to the following fixed-point problem

\footnotetext{
${ }^{14}$ For derivation, see Christensen and Spiegel (2021).
} 


$$
\hat{P}_{t}^{R}=C\left(t_{1}-t\right) \exp \left\{-\left(t_{1}-t\right) \hat{y}_{t}^{R}\right\}+\sum_{k=2}^{n} \frac{C}{2} \exp \left\{-\left(t_{k}-t\right) \hat{y}_{t}^{R}\right\}+\exp \left\{-(T-t) \hat{y}_{t}^{R}\right\},
$$

where $\hat{P}_{t}^{R}$ is the model-implied inflation-indexed bond price

$$
\begin{aligned}
\hat{P}_{t}^{R}= & C\left(t_{1}-t\right) \exp \left\{-\left(t_{1}-t\right) y_{t}^{R}\left(t_{1}-t\right)\right\} \\
& +\sum_{k=2}^{n} \frac{C}{2} \exp \left\{-\left(t_{k}-t\right) y_{t}^{R}\left(t_{k}-t,\right)\right\} \\
& +\exp \left\{-(T-t) y_{t}^{R}(T-t)\right\}+D O V_{t}\left(\frac{\Pi_{t}}{\Pi_{t_{0}}}\right)
\end{aligned}
$$

and $\Pi_{t} / \Pi_{t_{0}}$ is the accrued inflation compensation since issuance. That is, at time $t$ we use the real yields $y_{t}^{R}(\tau)$ in equation (1) to discount the coupon payments. $D O V_{t}$ in equation (4) represents the deflation option value. Principal at maturity is only adjusted for inflation if accumulated inflation since issuance of the bond is positive.

We include this option for the inflation-indexed bonds that have this contractual feature and compute it using an approach similar to the one outlined in Christensen et al. (2012). ${ }^{15}$ Following Joslin et al. (2011), all nominal yields have independent Gaussian measurement errors $\varepsilon_{t}^{N, i}$ with zero mean and a common standard deviation $\sigma_{\varepsilon}^{N}$, denoted $\varepsilon_{y, t}^{i} \sim \mathcal{N} \mathcal{I D}\left(0,\left(\sigma_{\varepsilon}^{N}\right)^{2}\right)$ for $i=1,2, \ldots, n_{N}$. We also account for measurement errors in the yields to maturity of the inflation-indexed bonds through $\varepsilon_{t}^{R, i}$, where $\varepsilon_{t}^{R, i} \sim \mathcal{N} \mathcal{I D}\left(0,\left(\sigma_{\varepsilon}^{R}\right)^{2}\right)$ for $i=1,2, \ldots, n_{R}(t)$.

\subsubsection{Survey Forecasts}

We also incorporate long-term forecasts of inflation from surveys of professional forecasters in our model estimation. These are the projected ten-year CPI inflation ex fresh food that can be constructed semi-annually from the Consensus Forecasts survey. ${ }^{16}$

As demonstrated by Kim and Orphanides (2012), the inclusion of long-term survey forecasts can help the model better capture the appropriate persistence of the factors under the objective $\mathbb{P}$-dynamics, which can otherwise suffer from significant finite-sample bias. ${ }^{17}$

The measurement equation for the survey expectations incorporating these long-term

\footnotetext{
${ }^{15}$ See Christensen and Spiegel (2021) for details. We do not account for the approximately 2.5 month lag in the inflation indexation. Grishchenko and Huang (2013) and D'Amico et al. (2018) find that this adjustment normally is within a few basis points for the implied yield on U.S. TIPS. It is likely to be very small for our Japanese data as well.

${ }^{16}$ Similar to Christensen et al. (2010) and Abrahams et al. (2016), we do not include inflation data in the model estimation. This omission is expected to, at most, have a small impact on our results due to the relatively long maturities of most of our real yield observations, see D'Amico et al. (2018) for evidence.

${ }^{17}$ Also, see Bauer et al. (2012).
} 


\begin{tabular}{c|cc}
\hline \hline Maturity & \multicolumn{2}{|c}{ Benchmark model } \\
\cline { 2 - 3 } in months & Mean & RMSE \\
\hline 6 & 5.92 & 9.85 \\
12 & 1.23 & 6.14 \\
24 & -4.30 & 7.49 \\
48 & -6.07 & 10.69 \\
84 & -0.79 & 11.70 \\
120 & 0.00 & 0.00 \\
\hline All maturities & -0.67 & 8.58 \\
\hline \hline
\end{tabular}

Table 2: Pricing Errors of Nominal Yields

This table reports the mean pricing errors (Mean) and the root mean-squared pricing errors (RMSE) of Japanese nominal yields in the $G^{J}(4)$ model. All errors are reported in basis points.

forecasts takes the form

$$
\pi_{t}^{C F}(10)=\pi_{t}^{e}(10)+\varepsilon_{t}^{C F}
$$

where $\pi_{t}^{e}(10)$ is the model-implied ten-year expected inflation calculated using equation (2), which is affine in the state variables, while the measurement error is $\varepsilon_{t}^{C F} \sim \mathcal{N} \mathcal{I D}\left(0,\left(\sigma_{\varepsilon}^{C F}\right)^{2}\right)$.

To improve the tractability of our model estimation, we impose the parameter restriction $\kappa_{44}^{\mathbb{P}}=\lambda^{R}$. This creates a direct connection between the $\mathbb{P}$ - and $\mathbb{Q}$-dynamics of the real yield slope factor $S_{t}^{R}$ that facilitates identification.

Regarding the empirical identification of the parameters in the volatility matrix $\Sigma$, note that since $\frac{A^{N}(\tau)}{\tau}$ contains three unique elements that are functions of $\tau$, the three volatility parameters $\sigma_{11}, \sigma_{21}$, and $\sigma_{22}$ can be empirically identified from solely observing nominal yields. In turn, this implies that the remaining seven volatility parameters $\left(\sigma_{31}, \sigma_{32}, \sigma_{33}, \sigma_{41}, \sigma_{42}, \sigma_{43}, \sigma_{44}\right)$ must be identified from real yields. However, it is clear from the real yield-adjustment term $\frac{A^{R}(\tau)}{\tau}$ that only three of these parameters can be econometrically identified as long as the information set is limited to nominal and real yields. Thus, in reality, only $\left(\sigma_{33}, \sigma_{43}, \sigma_{44}\right)$ can be identified. As a result, we can not estimate the volatility correlations between the nominal and real yield curve risk factors. We therefore restrict the volatility matrix $\Sigma$ to a diagonal matrix, as recommended by Christensen et al. (2011). ${ }^{18}$

Finally, we note that the model is estimated with the standard extended Kalman filter due to the nonlinear measurement equations for the inflation-indexed bond yields. ${ }^{19}$

\subsection{Estimation Results}

Table 2 documents that the benchmark model fits all of the nominal yields well, as the overall root mean-squared error (RMSE) is only 8.58 basis points.

\footnotetext{
${ }^{18}$ In principle, one could identify the remaining volatility parameters from the value of the deflation protection options. However, these bonds are quite limited in both number and sample period, limiting their value for identification.

${ }^{19}$ See Andreasen et al. (2019) for evidence of the robustness of this approach.
} 


\begin{tabular}{l|cc}
\hline \hline \multirow{2}{*}{ JGBi (coupon, maturity) } & \multicolumn{2}{|c}{ Pricing errors } \\
\cline { 2 - 3 } & Mean & RMSE \\
\hline (1) $1.2 \% 3 / 10 / 2014$ & -6.21 & 15.24 \\
(2) $1.1 \% 6 / 10 / 2014$ & 6.75 & 14.48 \\
(3) $0.5 \% 12 / 10 / 2014$ & -1.43 & 9.33 \\
(4) $0.5 \% 6 / 10 / 2015$ & 6.81 & 11.44 \\
(5) $0.8 \% 9 / 10 / 2015$ & 2.96 & 7.73 \\
(6) $0.8 \% 12 / 10 / 2015$ & -0.38 & 9.98 \\
(7) $0.8 \% 3 / 10 / 2016$ & -1.46 & 8.23 \\
(8) $1 \% 6 / 10 / 2016$ & 1.26 & 10.29 \\
(9) $1.1 \% 9 / 10 / 2016$ & -4.55 & 8.18 \\
(10) $1.1 \% 12 / 10 / 2016$ & -4.58 & 7.23 \\
(11) $1.2 \% 3 / 10 / 2017$ & -5.89 & 10.56 \\
(12) $1.2 \% 6 / 10 / 2017$ & 0.91 & 5.75 \\
(13) $1.3 \% 9 / 10 / 2017$ & -1.63 & 4.99 \\
(14) $1.2 \% 12 / 10 / 2017$ & 0.14 & 7.12 \\
(15) $1.4 \% 3 / 10 / 2018$ & -3.15 & 11.26 \\
(16) $1.4 \% 6 / 10 / 2018$ & 7.43 & 13.71 \\
(17) $0.1 \% 9 / 10 / 2023$ & 2.29 & 11.04 \\
(18) $0.1 \% 3 / 10 / 2024$ & 1.36 & 5.66 \\
(19) $0.1 \% 9 / 10 / 2024$ & 1.35 & 7.62 \\
(20) $0.1 \% 3 / 10 / 2025$ & 0.84 & 6.64 \\
(21) $0.1 \% 3 / 10 / 2026$ & -0.62 & 5.73 \\
(22) $0.1 \% 3 / 10 / 2027$ & -1.22 & 5.81 \\
(23) $0.1 \% 3 / 10 / 2028$ & 0.99 & 4.34 \\
(24) $0.1 \% 3 / 10 / 2029$ & 1.35 & 4.76 \\
(25) $0.2 \% 3 / 10 / 2030$ & -10.89 & 11.45 \\
(26) $0.005 \% 3 / 10 / 2031$ & -4.56 & 4.70 \\
\hline All yields & 0.07 & 9.46 \\
Max $\mathcal{L}^{E}$ K F & $20,279.21$ \\
\hline \hline
\end{tabular}

Table 3: Pricing Errors of Japanese Real Government Bond Yields to Maturity This table reports the mean pricing errors (Mean) and the root mean-squared pricing errors (RMSE) of Japanese inflation-indexed bond (JGBi) yields to maturity in the $G^{J}(4)$ model. The errors are computed as the difference between the observed yield to maturity downloaded from Bloomberg and the corresponding model-implied yield. All errors are reported in basis points.

The summary statistics of the fitted errors for each JGBi calculated as described in equation (3) are reported in Table 3. The RMSE for all yield errors combined is 9.46 basis points, which is only slightly above the corresponding statistic for the nominal yields. As such, we consider the model's fit to the real yield data to be satisfactory as well.

We also find that the estimated measurement error standard deviations within our benchmark model are $\sigma_{\varepsilon}^{N}=0.0011, \sigma_{\varepsilon}^{R}=0.0010$, and $\sigma_{\varepsilon}^{C F}=0.0015$, which also match well with the properties of the corresponding fitted error series.

Second, we report the estimated dynamic parameters of our benchmark model in Table 4. The volatility parameters in the $\Sigma$ matrix are estimated with precision. For the mean- 


\begin{tabular}{|c|cccc||c||c|c|}
\hline$K^{\mathbb{P}}$ & $K_{\cdot, 1}^{\mathbb{P}}$ & $K_{\cdot, 2}^{\mathbb{P}}$ & $K_{\cdot, 3}^{\mathbb{P}}$ & $K_{\cdot, 4}^{\mathbb{P}}$ & $\theta^{\mathbb{P}}$ & & $\Sigma$ \\
\hline$K_{1, \cdot}^{\mathbb{P}}$ & 3.6172 & 3.8878 & -0.2697 & -0.0347 & 0.0051 & $\Sigma_{1,1}$ & 0.0039 \\
& $(0.2394)$ & $(0.2698)$ & $(0.0989)$ & $(0.1018)$ & $(0.0092)$ & & $(0.0003)$ \\
$K_{2, \cdot}^{\mathbb{P}}$ & 0.0698 & 0.1865 & 0.0824 & 0.0757 & -0.0090 & $\Sigma_{2,2}$ & 0.0040 \\
& $(0.2339)$ & $(0.2656)$ & $(0.1085)$ & $(0.1144)$ & $(0.0085)$ & & $(0.0003)$ \\
$K_{3, \cdot}^{\mathbb{P}}$ & -2.3292 & -2.7275 & 0.3766 & 0.2821 & -0.0087 & $\Sigma_{3,3}$ & 0.0072 \\
& $(0.3157)$ & $(0.3360)$ & $(0.1013)$ & $(0.0776)$ & $(0.0000)$ & & $(0.0000)$ \\
$K_{4, \cdot}^{\mathbb{P}}$ & 3.0765 & 3.5579 & 0.2239 & 0.4240 & -0.0052 & $\Sigma_{4,4}$ & 0.0154 \\
& $(0.3087)$ & $(0.3534)$ & $(0.0608)$ & $(0.0095)$ & $(0.0000)$ & & $(0.0009)$ \\
\hline
\end{tabular}

Table 4: Estimated Benchmark Model Parameters

The estimated parameters for the mean-reversion matrix $K^{\mathbb{P}}$, the mean vector $\theta^{\mathbb{P}}$, and the volatility matrix $\Sigma$ in the $G^{J}(4)$ model. The $\mathbb{Q}$-related parameters are estimated at $\lambda^{N}=0.1099(0.0048)$ and $\lambda^{R}=\kappa_{44}^{\mathbb{P}}=0.4240$. The numbers in parentheses are the estimated standard deviations.

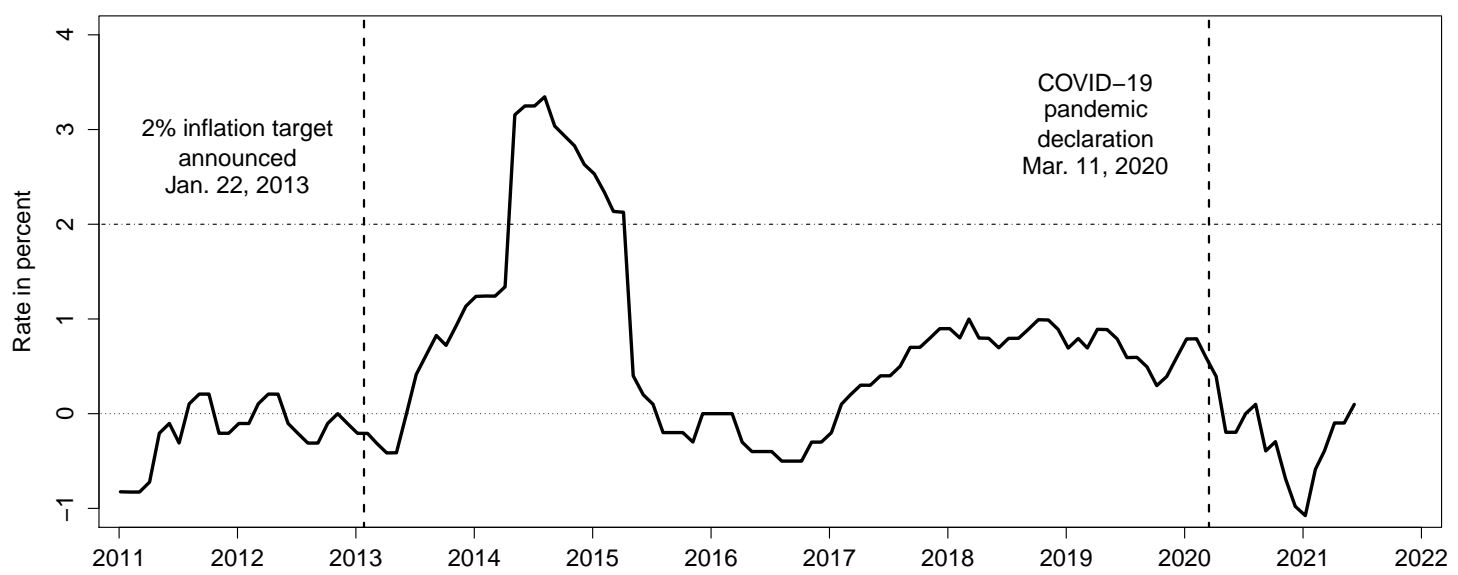

Figure 5: Japanese CPI Inflation ex Fresh Food

reversion parameters in the $K^{\mathbb{P}}$ matrix and the mean parameters in the $\theta^{\mathbb{P}}$ vector, the results are more mixed, in that some of them are highly statistically significant, while others are clearly insignificant.

\section{The COVID-19 Crisis}

In light of the unprecedented economic shock caused by the spread of COVID-19 in the spring of 2020, we fit our model through the end of June 2021 to examine whether the global pandemic had any impact on the long-term inflation expectations of investors in the Japanese government bond market. We also assess the outlook for long-term inflation expectations in Japan based on the estimated factor dynamics of the $G^{J}(4)$ model.

To begin with, Figure 5 shows the year-over-year change in the Japanese Consumer Price 


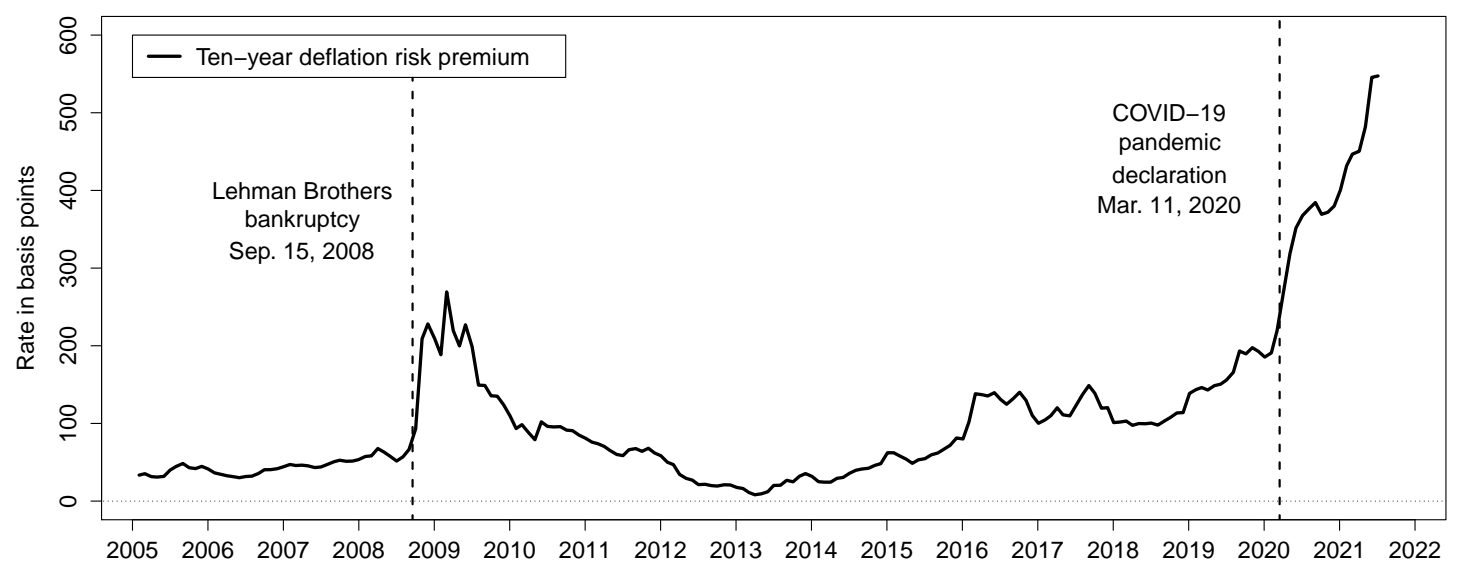

Figure 6: Value of Ten-Year Deflation Protection Options

Shown is the "deflation risk premium" defined as the spread between the par yield of a synthetic newly issued ten-year inflation-indexed bond lacking deflation protection and that of a deflation-protected bond with the same maturity.

Index (CPI), excluding fresh food since 2011. For the period before 2020, Japanese CPI inflation fluctuated below 1 percent except for a brief period in 2014 and early 2015 when it spiked above the BOJ's two percent target. Importantly, the spread of the coronavirus pandemic and the associated negative economic shock in the spring of 2020 caused another spell of deflation in Japan that persisted through the end of our sample. These developments are likely to have raised the value of deflation protection in the prices of JBGi's and put downward pressure on investors' inflation expectations. We rely on our model to examine these conjectures.

To have a consistent measure of deflation protection values across time, which is not affected by variation in inflation index ratios, coupon differences, and maturity mismatches, we construct synthetic ten-year real par-coupon yield spreads.

We calculate the deflation option values by comparing the prices of a newly issued JGBi without any accrued inflation compensation, but with deflation protection and a similar JGBi that does not offer this protection. First, consider the latter hypothetical JGBi with $T$ years remaining to maturity that pays an annual coupon $C$ semi-annually. As this bond does not offer any deflation protection, its par coupon is determined by the equation

$$
\sum_{i=1}^{2 T} \frac{C}{2} E_{t}^{Q}\left[e^{-\int_{t}^{t_{i}} r_{s}^{R} d s}\right]+E_{t}^{Q}\left[e^{-\int_{t}^{T} r_{s}^{R} d s}\right]=1
$$

The first term is the sum of the present value of the $2 T$ coupon payments using the model's fitted real yield curve at day $t$. The second term is the discounted value of the principal 
payment. The coupon rate that satisfies this equation will be denoted by $C_{N O}$.

Next, consider the corresponding JGBi with deflation protection, but no accrued inflation compensation. Since its coupon payments are not protected against deflation, the difference is in accounting for the deflation protection on the principal payment as explained in Section 3.3. Therefore, the par coupon for this bond is given by the solution to the following equation

$\sum_{i=1}^{2 T} \frac{C}{2} E_{t}^{Q}\left[e^{-\int_{t}^{t_{i}} r_{s}^{R} d s}\right]+E_{t}^{Q}\left[e^{-\int_{t}^{T} r_{s}^{R} d s}\right]+\left[E_{t}^{Q}\left[e^{-\int_{t}^{T} r_{s}^{N} d s} \mathbf{1}_{\left\{\frac{\Pi_{T}}{\Pi_{t}} \leq 1\right\}}\right]-E_{t}^{Q}\left[e^{-\int_{t}^{T} r_{s}^{R} d s} \mathbf{1}_{\left\{\frac{\Pi_{T}}{\Pi_{t}} \leq 1\right\}}\right]\right]=1$,

where the last term on the left-hand side represents the net present value of the deflation protection of the principal in the JGBi contract. We write $C_{O}$ for the par-coupon yield of the new hypothetical JGBi that satisfies this equation.

The difference between $C_{N O}$ and $C_{O}$ is a measure of the advantage of holding a newly issued JGBi at the inflation adjustment floor, and we refer to this as the deflation risk premium. Figure 6 shows the difference between the values of $C_{N O}$ and $C_{O}$ that satisfy the pricing equations at the ten-year maturity using our estimated benchmark model. Prior to the financial crisis, the differences between the two synthetic JGBi yields were on average less than 50 basis points. However, the yield differences then spiked with the onset of the crisis. After the crisis ended, the yield difference gradually declined and bottomed in the spring of 2013 when hopes for the success of Abenomics were at their peak. In the subsequent years, the yield difference trended higher again, reaching a plateau near 100 basis points in early 2016 where it remained until the pandemic hit. Note the dramatic increase in this premium since the start of the pandemic. It is estimated at more than 550 basis points at the end of June 2021, which dwarfs the otherwise high levels reached around the peak of the global financial crisis in 2008-2009. Consistent with our modeling approach, this sharp spike in the deflation risk premium embedded in JGBi prices coincides with the fact that the year-over-year change in the Japanese CPI turned negative in April 2020 and has remained mostly negative since then.

Figure 7 shows the ten-year BEI decomposition implied by our model. First, we note the huge wedge between the fitted and the option-adjusted BEI caused by the dramatic increase in the deflation risk premium. As a consequence, the option-adjustment provided by our model is more important and relevant than ever at the end of our sample. Crucially, the raw fitted ten-year BEI has actually trended higher since the onset of the pandemic. Thus, a policymaker just looking at this series might wrongly conclude that investors' long-term inflation expectations have firmed. The figure also shows the decomposition of the ten-year option-adjusted BEI into the ten-year expected inflation, shown with a solid red line, and the residual ten-year inflation risk premium, shown with a solid green line. At the end of February 2020, investors' ten-year expected inflation was estimated at 0.995 percent. Since then this measure of investors' long-term inflation expectations has declined 0.80 percentage 


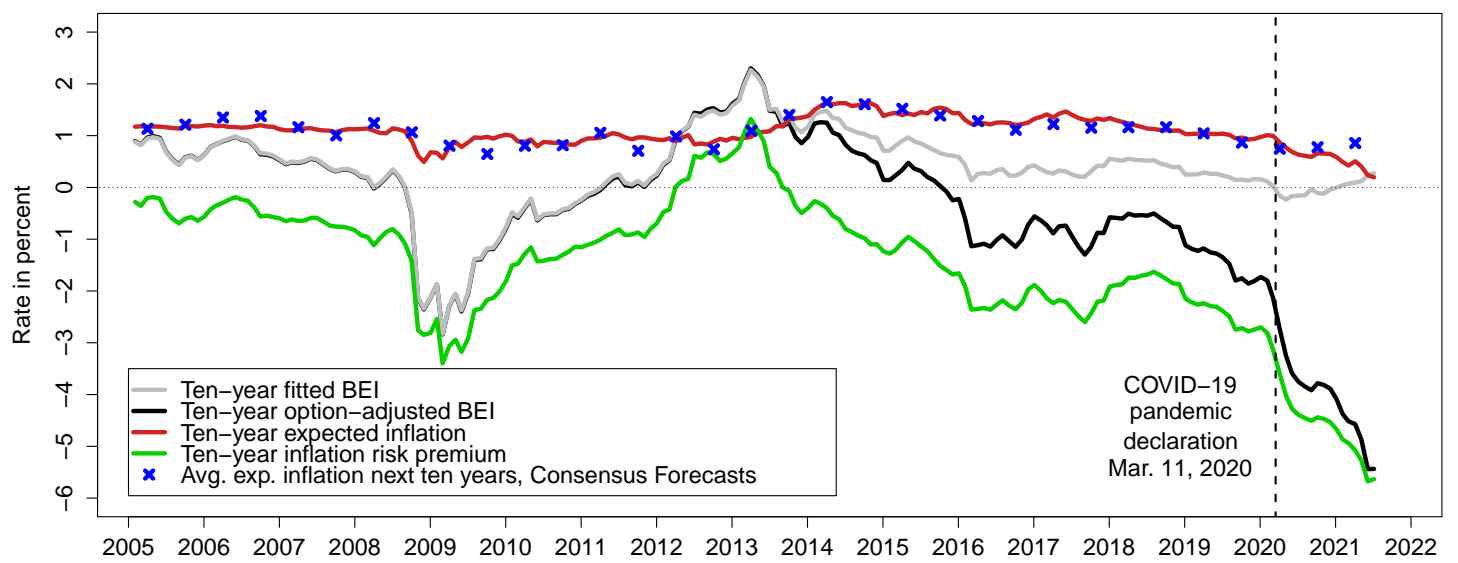

Figure 7: Decomposition of Ten-Year BEI

Illustration of the fitted ten-year BEI obtained by fitting the $G^{J}(4)$ model to nominal and real yields without any option adjustment or survey forecasts. Also shown are (i) the ten-year fitted optionadjusted break-even inflation (BEI) calculated as the difference between the fitted ten-year nominal yield and the fitted ten-year option-adjusted real yield from the $G^{J}(4)$ model, (ii) the estimated tenyear expected inflation, and (iii) the residual ten-year inflation risk premium. Finally, the semi-annual ten-year expected inflation series from the Consensus Forecasts survey is shown with blue crosses.

points leaving ten-year expected inflation at 0.196 percent at the end of June 2021. Changes in the inflation risk premium remain the main source of variation in the option-adjusted tenyear BEI. Lastly, Figure 7 also shows the semiannual ten-year inflation forecasts from the Consensus Forecasts survey that we use in the model estimation. At the end of June 2021, there is an unusually large and persistent wedge of 0.65 percent between the survey forecasts and the model-implied expected inflation at the ten-year horizon. This underscores that while the model tracks the survey forecasts relatively closely most of the time, it does not do so when yield information suggests otherwise.

Given the significant decline in the model-implied ten-year expected inflation since 2019, we assess the outlook for long-term inflation expectations in Japan. We simulate 10,000 factor paths over a ten-year horizon, conditioned on the shapes of the nominal and real yield curves and investors' embedded forward-looking expectations as of the end of June 2021 (that is, using estimated state variables and factor dynamics as of June 30, 2021). The simulated factor paths are then converted into forecasts of ten-year expected inflation. Figure 8 shows the median projection and the 5th and 95th percentile values for the simulated ten-year expected inflation over a ten-year forecast horizon. ${ }^{20}$

Our model projections indicate that the long-term inflation expectations are likely to

\footnotetext{
${ }^{20}$ Note that the lines do not represent paths from a single simulation run over the forecast horizon; instead, they delineate the distribution of all simulation outcomes at a given point in time.
} 


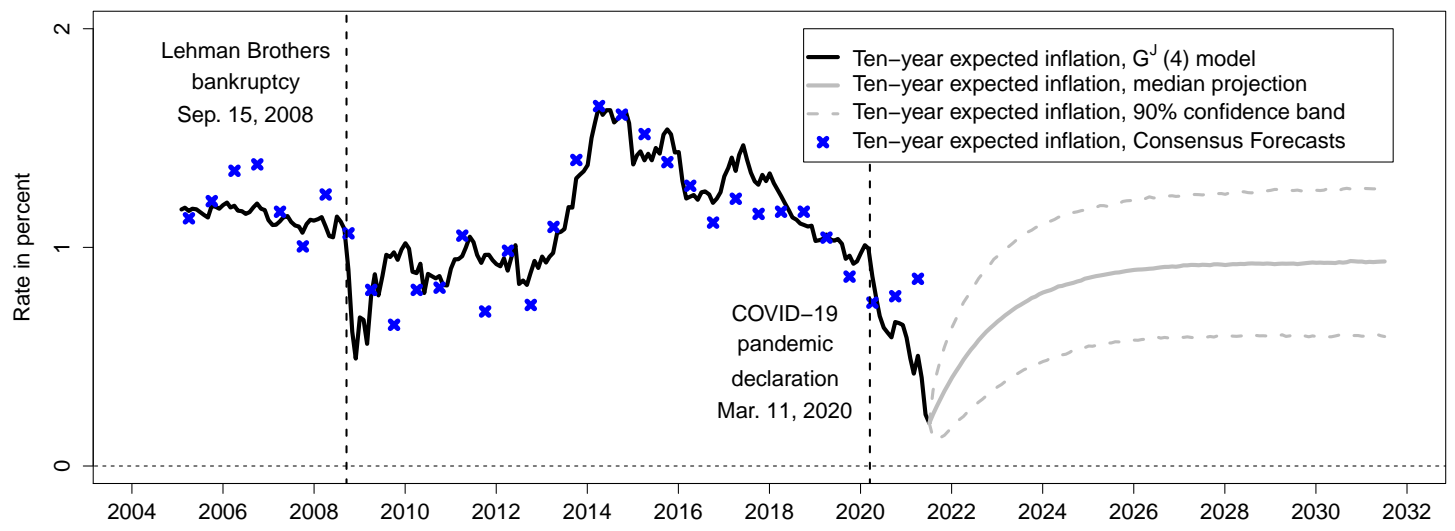

Figure 8: Ten-Year Projections of Ten-Year Expected Inflation

gradually reverse their recent declines and return to a level slightly below 1 percent by 2025 and remain there for the rest of the forecast period. This suggests that investors' long-term inflation expectations in Japan remain anchored near 1 percent, consistent with our survey evidence, despite the dramatic temporary downturn in domestic and global economic activity during the COVID-19 pandemic.

\section{$5 \quad$ Effects of Policy Responses to COVID-19}

In this section, we conduct event studies using our estimated benchmark model to evaluate the impact of specific recent BOJ and fiscal policy actions.

We use our model to decompose the one-day breakeven inflation reactions with and without option adjustment. We focus on ten-year yields in line with the existing literature. ${ }^{21}$ Recall that the decomposition of BEI rates is given by

$$
B E I_{t}(\tau)=y_{t}^{N}(\tau)-y_{t}^{R}(\tau)=\pi_{t}^{e}(\tau)+\phi_{t}(\tau)
$$

where $\pi_{t}^{e}(\tau)$ is the market-implied average rate of inflation expected at time $t$ for the period from $t$ to $t+\tau$, while $\phi_{t}(\tau)$ is the associated inflation risk premium.

Figure 9 shows the decomposition of the ten-year fitted option-adjusted BEI. As ten-year expected inflation has remained relatively stable during most of our sample starting in 2005, the large variation in the fitted ten-year BEI is almost entirely driven by changes in the inflation risk premium, which has been negative most of this period.

\footnotetext{
${ }^{21}$ Ten-year yields are commonly used as the benchmark long-term yield in most government bond markets, including Japan. They also have served as the most popular maturity for studies of financial market reactions to unconventional monetary policies [e.g. Gagnon et al. (2011), Christensen and Rudebusch (2012), and Christensen and Krogstrup (2019)]. Also, Japanese short- and medium-term nominal yields were constrained near the zero lower bound for most of our sample.
} 


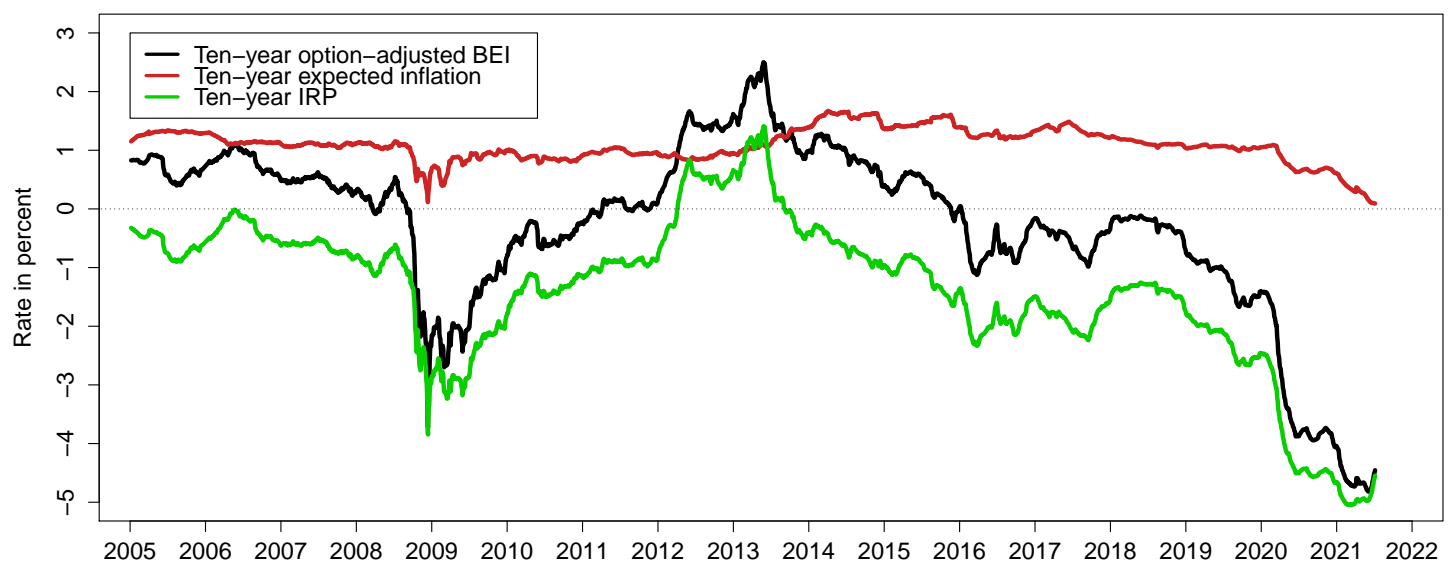

Figure 9: Ten-Year Option-Adjusted BEI Decomposition

As shown in the figure, the inflation risk premium did turn positive during 2012, coinciding with increasing optimism about the Abe reforms. However, it has been on a downward trajectory since the spring of 2013. The negative inflation risk premium that has prevailed since then implies that bond investors view future economic downturns as likely to coincide with low inflation.

We are interested in examining to what extent monetary and fiscal policy interventions countered the decline by more than 350 basis points in the ten-year option-adjusted BEI since the beginning of 2020, and the decline by 80 basis points in the model-implied tenyear expected inflation over the same period. To achieve this, we rely on a high frequency event study based on our models estimated with daily data. This allows us to isolate the implications of the announcements of pursued monetary and fiscal policies. Finally, as a benchmark with which to gauge the identified reactions, we also examine the response of the market to news about major pandemic-related shutdowns.

\subsection{Key Monetary Policy Announcements}

The monetary policy responses to the pandemic that we study are listed in Table 5 and include a reduction by 25 basis points in the loan rate, increases in the purchases of commercial paper (CP), as well as purchases of ETFs and J-REITs on March 16, 2020; the establishment of an interest scheme to promote lending, a commitment to keep 10-year JGB yields within 25 basis points of the target level, and forward guidance on continued purchases of ETFs and J-REITs even after the end of the COVID crisis on March 19, 2020; a further increase in purchases of CP and corporate debt to $¥ 20$ trillion, a strengthening of Special Funds operations, which entailed the expansion of the range of eligible collateral for private debt, including household 


\begin{tabular}{|c|c|c|}
\hline No. & Date & Announcement description \\
\hline I & Mar. 16, 2020 & $\begin{array}{l}\text { Enhancements of monetary easing. Lowered loan rate } 25 \text { bp. Facil- } \\
\text { itate corporate borrowing by increasing pace of CP purchases. Pur- } \\
\text { chases of ETFs and J-REITs. }\end{array}$ \\
\hline II & Mar. 19, 2020 & $\begin{array}{l}\text { Further enhancements. Establish interest scheme to promote lend- } \\
\text { ing. 10-yr JGB to be within } 25 \text { bps of target. Commit to purchase of } \\
\text { ETFs and J-REITS even after COVID subsides. }\end{array}$ \\
\hline III & Apr. 27, 2020 & $\begin{array}{l}\text { Enhancement of Monetary easing. Increase CP and corporate debt } \\
\text { purchases to } ¥ 20 \text { trillion. Strengthen Special Funds supplying op- } \\
\text { erations: Expand range of eligible collateral to private debt includ- } \\
\text { ing household debt from } ¥ 8 \text { trillion to } ¥ 23 \text { trillion, increase eligible } \\
\text { counterparties for loans held at BOJ. Increase purchases of JGBs and } \\
\text { treasury bills. }\end{array}$ \\
\hline IV & May 22,2020 & $\begin{array}{l}\text { New fund-provisioning measure. Interest free and secured loans to el- } \\
\text { igible counterparties of } ¥ 30 \text { trillion based on government emergency } \\
\text { measures. }\end{array}$ \\
\hline $\mathrm{V}$ & Mar. 19, 2021 & $\begin{array}{l}\text { Further effective and sustainable monetary easing. Establish inter- } \\
\text { est scheme to promote lending. Range of 10-year yield will be kept } \\
\text { around zero plus and minus } 0.25 \text { percent. Purchases of ETFs and } \\
\text { J-REITS (at same pace as before). }\end{array}$ \\
\hline
\end{tabular}

Table 5: Key Monetary Policy Announcements by the Bank of Japan

debt from $¥ 8$ trillion to $¥ 23$ trillion, an increase in eligible counterparties for loans held at the BOJ, and an increase in purchases of JGBs and treasury bills on April 27, 2020; a new fundprovisioning measure, which allowed interest free and secured loans to eligible counterparties of $¥ 30$ trillion based on government emergency measures on May 22, 2020, and finally an interest scheme to promote lending on March 19, 2021.

Table 7 reports the daily changes in the ten-year BEI decomposition around the five BOJ announcements. Overall, we find that none of the monetary policy responses studied succeeded in raising the ten-year BEI. Instead, we observe modest declines in the ten-year BEI, by between 0 and 10 basis points.

Moreover, Table 6 demonstrates that for some of our studied monetary events, adjusting for the deflation protection option affects the qualitative impacts of the announcements. In particular, for the March 16 announcement of monetary easing, the change in ten-year BEI fell from -6 basis points to -10 basis points, while for the March 18 announcement of further enhancements, the ten-year BEI fell from an increase of 2 basis points to a decline of 4 basis points after adjusting for deflation protection. However, in these cases, the primary shift was attributable to a change in the inflation risk premium, with the change in tenyear inflation expectations for the first event remaining at -2 basis points and the change in inflation expectations for the second event only falling by one basis point. 


\begin{tabular}{|c|c|c|c|c|c|c|}
\hline \multirow{2}{*}{\multicolumn{2}{|c|}{ Event }} & \multicolumn{5}{|c|}{ Fitted BEI } \\
\hline & & 1-year & 2-year & 5-year & 7-year & 10-year \\
\hline \multirow{3}{*}{ I } & Mar. 13,2020 & -43.3 & -38.5 & -28.1 & -22.9 & -16.3 \\
\hline & Mar. 16, 2020 & -51.2 & -45.9 & -34.5 & -29.0 & -22.1 \\
\hline & Change & -7.9 & -7.4 & -6.4 & -6.1 & -5.8 \\
\hline \multirow{3}{*}{ II } & Mar. 18, 2020 & -48.2 & -44.1 & -34.6 & -29.6 & -23.0 \\
\hline & Mar. 19, 2020 & -44.4 & -40.9 & -32.2 & -27.5 & -21.1 \\
\hline & Change & 3.7 & 3.2 & 2.3 & 2.1 & 2.0 \\
\hline \multirow{3}{*}{ III } & Apr. 24, 2020 & -23.7 & -25.5 & -25.2 & -22.9 & -18.1 \\
\hline & Apr. 27, 2020 & -25.4 & -27.3 & -27.1 & -24.8 & -20.0 \\
\hline & Change & -1.7 & -1.8 & -1.9 & -1.9 & -1.9 \\
\hline \multirow{3}{*}{ IV } & May 21,2020 & -19.0 & -20.3 & -19.0 & -16.3 & -11.2 \\
\hline & May 22,2020 & -19.7 & -21.2 & -20.2 & -17.6 & -12.5 \\
\hline & Change & -0.6 & -0.8 & -1.2 & -1.3 & -1.3 \\
\hline \multirow{3}{*}{$\mathrm{V}$} & Mar. 18, 2021 & 31.3 & 22.9 & 13.0 & 12.5 & 15.2 \\
\hline & Mar. 19, 2021 & 31.7 & 23.1 & 12.9 & 12.3 & 14.9 \\
\hline & Change & 0.4 & 0.2 & -0.1 & -0.2 & -0.3 \\
\hline \multirow{2}{*}{\multicolumn{2}{|c|}{ Event }} & \multicolumn{5}{|c|}{ Option-Adjusted BEI } \\
\hline & & 1-year & 2-year & 5-year & 7-year & 10-year \\
\hline \multirow{3}{*}{$\mathrm{I}$} & Mar. 13,2020 & 100.2 & 20.8 & -122.6 & -173.7 & -218.1 \\
\hline & Mar. 16, 2020 & 86.7 & 8.1 & -134.0 & -184.5 & -228.4 \\
\hline & Change & -13.4 & -12.7 & -11.3 & -10.8 & -10.2 \\
\hline \multirow{3}{*}{ II } & Mar. 18, 2020 & 67.3 & -10.5 & -150.7 & -200.5 & -243.5 \\
\hline & Mar. 19, 2020 & 61.2 & -16.2 & -155.6 & -205.1 & -247.7 \\
\hline & Change & -6.0 & -5.7 & -4.9 & -4.6 & -4.2 \\
\hline \multirow{3}{*}{ III } & Apr. 24, 2020 & -64.0 & -133.0 & -256.2 & -299.1 & -335.0 \\
\hline & Apr. 27, 2020 & -67.1 & -136.0 & -258.9 & -301.6 & -337.4 \\
\hline & Change & -3.1 & -2.9 & -2.7 & -2.5 & -2.4 \\
\hline \multirow{3}{*}{ IV } & May 21,2020 & -107.7 & -172.9 & -289.2 & -329.5 & -363.1 \\
\hline & May 22,2020 & -109.7 & -174.8 & -290.8 & -331.0 & -364.5 \\
\hline & Change & -2.1 & -1.9 & -1.6 & -1.5 & -1.4 \\
\hline \multirow{3}{*}{$\mathrm{V}$} & Mar. 18, 2021 & -339.4 & -374.9 & -436.8 & -457.2 & -472.9 \\
\hline & Mar. 19, 2021 & -341.7 & -376.7 & -437.6 & -457.7 & -473.2 \\
\hline & Change & -2.3 & -1.8 & -0.9 & -0.5 & -0.1 \\
\hline
\end{tabular}

Table 6: One-Day Responses of Japanese BEI to Bank of Japan Announcements The table reports the one-day response of Japanese BEI at five different maturities around the BOJ announcement dates. All numbers are measured in basis points. 


\begin{tabular}{|c|l|c|c||c|}
\hline \multicolumn{4}{|l}{ Decomposition from $G^{J}(4)$ model without option adjustment } \\
\hline \hline \multirow{2}{*}{ Event } & $\begin{array}{c}\text { Ten-year exp. } \\
\text { inflation }\end{array}$ & $\begin{array}{c}\text { Ten-year } \\
\text { IRP }\end{array}$ & $\begin{array}{c}\text { Ten-year } \\
\text { BEI }\end{array}$ \\
\hline \hline \multirow{3}{*}{ I } & Mar. 13, 2020 & 81 & -97 & -16 \\
& Mar. 16, 2020 & 79 & -101 & -22 \\
\cline { 2 - 5 } & Change & $\mathbf{- 2}$ & $\mathbf{- 4}$ & $\mathbf{- 6}$ \\
\hline \hline \multirow{3}{*}{ II } & Mar. 18, 2020 & 79 & -102 & -23 \\
& Mar. 19, 2020 & 79 & -100 & -21 \\
\cline { 2 - 5 } & Change & $\mathbf{0}$ & $\mathbf{2}$ & $\mathbf{2}$ \\
\hline \hline \multirow{3}{*}{ III } & Apr. 24, 2020 & 84 & -102 & -18 \\
& Apr. 27, 2020 & 84 & -104 & -20 \\
\cline { 2 - 5 } & Change & $\mathbf{0}$ & $\mathbf{- 2}$ & $\mathbf{- 2}$ \\
\hline \hline \multirow{3}{*}{ IV } & May 21, 2020 & 85 & -96 & -11 \\
& May 22, 2020 & 85 & -97 & -13 \\
\cline { 2 - 5 } & Change & $\mathbf{0}$ & $\mathbf{- 1}$ & $\mathbf{- 1}$ \\
\hline \hline \multirow{3}{*}{ V } & Mar. 18, 2021 & 93 & -78 & 15 \\
& Mar. 19, 2021 & 93 & -78 & 15 \\
\cline { 2 - 5 } & Change & $\mathbf{0}$ & $\mathbf{0}$ & $\mathbf{0}$ \\
\hline
\end{tabular}

\begin{tabular}{|c|l|c|c||c|}
\hline \multicolumn{2}{|c|}{ Decomposition from $G^{J}(4)$ model with option adjustment } \\
\hline \hline \multirow{2}{*}{ Event } & $\begin{array}{c}\text { Ten-year exp. } \\
\text { inflation }\end{array}$ & $\begin{array}{c}\text { Ten-year } \\
\text { IRP }\end{array}$ & $\begin{array}{c}\text { Ten-year } \\
\text { BEI }\end{array}$ \\
\hline \hline \multirow{3}{*}{ I } & Mar. 13, 2020 & 102 & -321 & -218 \\
& Mar. 16, 2020 & 100 & -328 & -228 \\
\cline { 2 - 5 } & Change & $\mathbf{- 2}$ & $\mathbf{- 8}$ & $\mathbf{- 1 0}$ \\
\hline \hline \multirow{3}{*}{ II } & Mar. 18, 2020 & 97 & -340 & -243 \\
& Mar. 19, 2020 & 96 & -344 & -248 \\
\cline { 2 - 5 } & Change & $\mathbf{- 1}$ & $\mathbf{- 3}$ & $\mathbf{- 4}$ \\
\hline \hline \multirow{3}{*}{ III } & Apr. 24, 2020 & 77 & -412 & -335 \\
& Apr. 27, 2020 & 77 & -414 & -337 \\
\cline { 2 - 5 } & Change & $\mathbf{0}$ & $\mathbf{- 2}$ & $\mathbf{- 2}$ \\
\hline \hline \multirow{3}{*}{ IV } & May 21, 2020 & 70 & -433 & -363 \\
& May 22, 2020 & 70 & -434 & -364 \\
\cline { 2 - 5 } & Change & $\mathbf{0}$ & $\mathbf{- 1}$ & $\mathbf{- 1}$ \\
\hline \hline \multirow{3}{*}{ V } & Mar. 18, 2021 & 31 & -504 & -473 \\
\cline { 2 - 5 } & Mar. 19, 2021 & 30 & -503 & -473 \\
\cline { 2 - 5 } & Change & $\mathbf{0}$ & $\mathbf{0}$ & $\mathbf{0}$ \\
\hline
\end{tabular}

Table 7: Decomposition of One-Day Responses of the Ten-Year BEI to Bank of Japan Announcements

The decomposition of one-day responses of the Japanese ten-year BEI on five BOJ announcement dates into changes in (i) the ten-year expected inflation and (ii) the ten-year inflation risk premium (IRP) based on the $G^{J}(4)$ model estimated with daily data and including the Consensus Forecasts of ten-year CPI inflation. All numbers are measured in basis points. 


\section{$5.2 \quad$ Key Fiscal Responses}

We consider seven key fiscal policy announcements, with announcement dates taken from KMPG Insights (2020), which are listed in Table 8. As the COVID crisis deepened, the Japanese government introduced a variety of extensions and expansions of existing support packages. Overall, the total announced fiscal stimulus amounted to about $\$ 3$ trillion, or 60 percent of Japanese nominal GDP, although, as noted in the introduction, actual added spending was closer to 16 percent of nominal GDP.

Our first event is the first emergency response package, announced on February 13, 2020. This package was modest in scope (\$96 million), coming on the tails of the $\$ 120$ billion preCOVID package introduced in late 2019 to stimulate the Japanese economy following a tax increase and a damaging typhoon, see Dooley and Yamamitsu (2020). The package included true pandemic-related emergency measures, such as travel assistance for Japanese nationals abroad and loan support for small and medium-sized enterprises (KPMG (2020)).

The second emergency package, announced on March 10, 2020, was more substantial. It was valued at $\$ 9.6$ billion, with half of the funds earmarked for zero-interest loans for small and medium-sized companies and most of the remainder for fiscal assistance, including hospital assistance and subsidies for workers that had to give up employment to care for children, see KPMG (2020) and Kyodo News (2020).

The third emergency response package, announced on April 7, 2020, was Japan's largest to date. Then Prime Minister Shinzo Abe declared a state of emergency and announced a $\$ 989$ billion stimulus package aimed at assisting Tokyo and six other economic hubs in the nation, see Takeo et al. (2020).

A substantial expansion of the third emergency response package was announced on April 20, 2020. Among other additions, that extension expanded distribution of cash payments of $¥ 100,000$ to each Japanese resident and deferred tax and social security premium payments. Overall, the expansion raised the fiscal stimulus to $\$ 1.1$ trillion, see Prime Minister of Japan and his Cabinet (2020).

Our fifth event is a fourth emergency response package containing an additional $\$ 1.1$ trillion in stimulus, announced on May 27, 2020. The package included rent support for small and medium-sized enterprises and subordinated loans for large companies (KPMG (2020)).

Our next event captures the direction on November 10, 2020, by new Prime Minister Suga to his cabinet to compile a new stimulus package. Economy Minister Nishimura revealed at the time that the new package would be between $\$ 95$ billion and $\$ 286$ billion in size, with spending more directed towards sectors with greater perceived needs (Takemoto and Leussink (2020)).

Finally, we consider the effects of the fifth emergency response package, announced on December 7, 2020. That package totaled $\$ 708$ billion, and was designed to accelerate the country's recovery from COVID-19, while also targeting reduced carbon emissions and digital 


\begin{tabular}{|c|c|c|}
\hline No. & Date & Announcement description \\
\hline $\mathrm{I}$ & Feb. 13, 2020 & First COVID-19 emergency response package announced. \\
\hline II & Mar. 10, 2020 & Second COVID-19 emergency response package announced. \\
\hline III & Apr. 7, 2020 & Third COVID-19 emergency response package announced. \\
\hline IV & Apr. 20, 2020 & $\begin{array}{l}\text { Emergency economic measures to cope with the first COVID-19 } \\
\text { package announced. }\end{array}$ \\
\hline $\mathrm{V}$ & May 27, 2020 & $\begin{array}{l}\text { Fourth COVID-19 emergency response package announced. Emer- } \\
\text { gency economic measures to cope with the second COVID-19 pack- } \\
\text { age announced. }\end{array}$ \\
\hline VI & Nov. 10,2020 & $\begin{array}{l}\text { New Prime Minister Suga orders supplementary budget for addi- } \\
\text { tional stimulus. }\end{array}$ \\
\hline VII & Dec. 7,2020 & $\begin{array}{l}\text { Fifth COVID-19 emergency response package announced, with } \$ 708 \\
\text { billion in new funds, bringing combined stimulus to } \$ 3 \text { trillion, or } \\
60 \% \text { of the Japanese economy (Reuters Dec. } 12,2020) \text {. }\end{array}$ \\
\hline
\end{tabular}

Table 8: Key Fiscal Policy Announcements

innovation, see Kihara and Kajimoto (2020).

Table 9 reports the daily changes in BEI rates around the seven fiscal policy announcements. As was the case for the monetary easing announcements, the seven fiscal expansions in our study do not appear to have generated persistent changes in BEI. They appear to be slightly more expansionary, but still very small. The only events that yielded non-negative responses in the ten-year BEI rate were the supplementary emergency response package (event IV), the fourth emergency response package (event V), and the supplementary budget directive under new Prime Minister Suga (event VI). Moreover, these were universally small, registering movements of $0.7,0.0$, and 1.5 basis points, respectively.

As before, it is also the case that the impact of adjusting for the deflation option is notable. Once we account for the deflation option embedded in these bonds, the ten-year option adjusted BEIs for the three aforementioned events all dip into negative territory, albeit again with relatively modest absolute values.

In light of the small changes registered in the fitted BEI rates, it is unsurprising that our model decompositions of the ten-year BEI responses reported in Table 10 are modest in magnitude as well. Overall, the fiscal measures had zero or a slightly negative impact on the estimated ten-year inflation expectations. Hence, there is no evidence to suggest that the fiscal measures helped better anchor long-term inflation expectations in Japan. Equally importantly, despite the large size of all the fiscal measures combined, they did not give rise to speculation about causing inflationary pressures in the Japanese economy, which contrasts with the situation in the U.S. and other major advanced economies. 


\begin{tabular}{|c|c|c|c|c|c|c|}
\hline \multirow{2}{*}{\multicolumn{2}{|c|}{ Event }} & \multicolumn{5}{|c|}{ Fitted BEI } \\
\hline & & 1-year & 2-year & 5 -year & 7 -year & 10-year \\
\hline \multirow{3}{*}{ I } & Feb. 12,2020 & 23.6 & 17.1 & 8.9 & 7.9 & 9.2 \\
\hline & Feb. 13,2020 & 23.4 & 16.9 & 8.7 & 7.7 & 9.0 \\
\hline & Change & -0.2 & -0.2 & -0.2 & -0.2 & -0.2 \\
\hline \multirow{3}{*}{ II } & Mar. 9, 2020 & 7.5 & 4.2 & 1.5 & 2.4 & 5.4 \\
\hline & Mar. 10, 2020 & 1.8 & 0.0 & -0.5 & 1.1 & 4.8 \\
\hline & Change & -5.7 & -4.3 & -2.0 & -1.2 & -0.6 \\
\hline \multirow{3}{*}{ III } & Apr. 6,2020 & -26.5 & -26.1 & -22.1 & -18.7 & -13.1 \\
\hline & Apr. 7, 2020 & -26.9 & -26.4 & -22.4 & -18.9 & -13.3 \\
\hline & Change & -0.4 & -0.4 & -0.3 & -0.3 & -0.2 \\
\hline \multirow{3}{*}{ IV } & Apr. 17,2020 & -25.9 & -26.9 & -25.0 & -22.1 & -16.8 \\
\hline & Apr. 20,2020 & -23.7 & -25.0 & -23.8 & -21.2 & -16.1 \\
\hline & Change & 2.3 & 1.8 & 1.1 & 0.9 & 0.7 \\
\hline \multirow{3}{*}{$\mathrm{V}$} & May 26, 2020 & -18.4 & -20.6 & -20.7 & -18.4 & -13.7 \\
\hline & May 27,2020 & -17.5 & -19.9 & -20.4 & -18.2 & -13.6 \\
\hline & Change & 0.9 & 0.7 & 0.3 & 0.2 & 0.0 \\
\hline \multirow{3}{*}{ VI } & Nov. 9,2020 & -33.7 & -30.0 & -20.5 & -15.1 & -7.7 \\
\hline & Nov. 10,2020 & -31.7 & -28.1 & -18.9 & -13.5 & -6.2 \\
\hline & Change & 2.0 & 1.9 & 1.7 & 1.6 & 1.5 \\
\hline \multirow{3}{*}{ VII } & Dec. 4,2020 & -11.7 & -12.1 & -9.6 & -6.6 & -1.3 \\
\hline & Dec. 7,2020 & -10.9 & -11.7 & -9.8 & -7.0 & -1.9 \\
\hline & Change & 0.8 & 0.4 & -0.2 & -0.4 & -0.6 \\
\hline \multirow{2}{*}{\multicolumn{2}{|c|}{ Event }} & \multicolumn{5}{|c|}{ Option-Adjusted BEI } \\
\hline & & 1-year & 2-year & 5-year & 7-year & 10-year \\
\hline \multirow{3}{*}{ I } & Feb. 12, 2020 & 137.0 & 62.8 & -71.3 & -119.1 & -160.5 \\
\hline & Feb. 13,2020 & 137.7 & 63.1 & -71.7 & -119.8 & -161.5 \\
\hline & Change & 0.7 & 0.3 & -0.5 & -0.7 & -1.0 \\
\hline \multirow{3}{*}{ II } & Mar. & 123 & 43.1 & -102.2 & -154.0 & -199.0 \\
\hline & Mar. 10, 2020 & 124.2 & 43.8 & -101.6 & -153.4 & -198.4 \\
\hline & Change & 0.7 & 0.7 & 0.6 & 0.6 & 0.6 \\
\hline \multirow{3}{*}{ III } & Apr. 6, 2020 & 1.4 & -72.3 & -204.3 & -250.6 & -290.0 \\
\hline & Apr. 7, 2020 & -3.5 & -76.9 & -208.4 & -254.5 & -293.7 \\
\hline & Change & -4.9 & -4.6 & -4.1 & -3.9 & -3.7 \\
\hline \multirow{3}{*}{ IV } & Apr. 17, 2020 & -44.7 & -115.1 & -240.8 & -284.6 & -321.5 \\
\hline & Apr. 20, 2020 & -48.9 & -118.9 & -243.9 & -287.4 & -324.0 \\
\hline & Change & -4.2 & -3.8 & -3.1 & -2.8 & -2.6 \\
\hline \multirow{3}{*}{$\mathrm{V}$} & May 26, & -114.0 & -178.7 & -293.8 & -333.7 & -366.9 \\
\hline & May 27,2020 & -116.1 & -180.6 & -295.4 & -335.1 & -368.2 \\
\hline & Change & -2.1 & -1.9 & -1.6 & -1.4 & -1.3 \\
\hline \multirow{3}{*}{ VI } & Nov. 9, 2020 & -104.9 & -173.7 & -296.6 & -339.3 & -375.3 \\
\hline & Nov. 10,2020 & -105.7 & -174.4 & -297.1 & -339.8 & -375.8 \\
\hline & Change & -0.7 & -0.7 & -0.5 & -0.5 & -0.5 \\
\hline \multirow{3}{*}{ VII } & Dec. 4,2020 & -133.6 & -199.4 & -317.1 & -358.1 & -392.6 \\
\hline & Dec. 7,2020 & -137.4 & -202.8 & -319.8 & -360.6 & -395.0 \\
\hline & Change & -3.8 & -3.4 & -2.8 & -2.6 & -2.4 \\
\hline
\end{tabular}

Table 9: One-Day Responses of Japanese BEI to Announcements of Fiscal Measures

The table reports the one-day response of Japanese BEI at five different maturities around seven fiscal policy announcement dates. All numbers are meas 26 red in basis points. 


\begin{tabular}{|c|c|c|c|c|}
\hline \multicolumn{5}{|c|}{ Decomposition from $G^{J}(4)$ model without option adjustment } \\
\hline \multicolumn{2}{|c|}{ Event } & $\begin{array}{l}\text { Ten-year exp. } \\
\text { inflation }\end{array}$ & $\begin{array}{l}\text { Ten-year } \\
\text { IRP }\end{array}$ & $\begin{array}{c}\text { Ten-year } \\
\text { BEI }\end{array}$ \\
\hline \multirow{3}{*}{ I } & Feb. 12, 2020 & 91 & -82 & 9 \\
\hline & Feb. 13,2020 & 91 & -82 & 9 \\
\hline & Change & $\mathbf{0}$ & 0 & $\mathbf{0}$ \\
\hline \multirow{3}{*}{ II } & Mar. 9, 2020 & 91 & -86 & 5 \\
\hline & Mar. 10, 2020 & 90 & -85 & 5 \\
\hline & Change & -1 & 1 & -1 \\
\hline \multirow{3}{*}{ III } & Apr. 6, 2020 & 83 & -96 & -13 \\
\hline & Apr. 7, 2020 & 83 & -96 & -13 \\
\hline & Change & 0 & 0 & 0 \\
\hline \multirow{3}{*}{ IV } & Apr. 16, 2020 & 83 & -100 & -17 \\
\hline & Apr. 17,2020 & 83 & -100 & -16 \\
\hline & Change & $\mathbf{0}$ & 0 & 1 \\
\hline \multirow{3}{*}{$\mathrm{V}$} & May 26,2020 & 85 & -98 & -14 \\
\hline & May 27,2020 & 85 & -98 & -14 \\
\hline & Change & $\mathbf{0}$ & 0 & $\mathbf{0}$ \\
\hline \multirow{3}{*}{ VI } & Nov. 9, 2020 & 82 & -90 & -8 \\
\hline & Nov. 10,2020 & 82 & -88 & -6 \\
\hline & Change & $\mathbf{0}$ & 1 & 2 \\
\hline \multirow{3}{*}{ VII } & Dec. 4,2020 & 85 & -87 & -1 \\
\hline & Dec. 7,2020 & 85 & -87 & -2 \\
\hline & Change & 0 & -1 & -1 \\
\hline
\end{tabular}

\begin{tabular}{|c|l|c|c||c|}
\hline \multicolumn{4}{|c|}{ Decomposition from $G^{J}(4)$ model with option adjustment } \\
\hline \hline \multirow{2}{|c|}{ Event } & $\begin{array}{c}\text { Ten-year exp. } \\
\text { inflation }\end{array}$ & $\begin{array}{c}\text { Ten-year } \\
\text { IRP }\end{array}$ & $\begin{array}{c}\text { Ten-year } \\
\text { BEI }\end{array}$ \\
\hline \hline \multirow{3}{*}{ I } & Feb. 12, 2020 & 108 & -268 & -161 \\
& Feb. 13, 2020 & 108 & -269 & -162 \\
\cline { 2 - 5 } & Change & $\mathbf{0}$ & $\mathbf{- 1}$ & $\mathbf{- 1}$ \\
\hline \hline \multirow{3}{*}{ II } & Mar. 9, 2020 & 108 & -307 & -199 \\
& Mar. 10, 2020 & 107 & -306 & -198 \\
\cline { 2 - 5 } & Change & $\mathbf{0}$ & $\mathbf{1}$ & $\mathbf{1}$ \\
\hline \hline \multirow{3}{*}{ III } & Apr. 6, 2020 & 87 & -377 & -290 \\
& Apr. 7, 2020 & 86 & -380 & -294 \\
\cline { 2 - 5 } & Change & $\mathbf{- 1}$ & $\mathbf{- 3}$ & $\mathbf{- 4}$ \\
\hline \hline \multirow{3}{*}{ IV } & Apr. 16, 2020 & 80 & -402 & -321 \\
& Apr. 17, 2020 & 79 & -403 & -324 \\
\cline { 2 - 5 } & Change & $\mathbf{- 1}$ & $\mathbf{- 2}$ & $\mathbf{- 3}$ \\
\hline \hline \multirow{3}{*}{ V } & May 26, 2020 & 69 & -436 & -367 \\
& May 27, 2020 & 68 & -437 & -368 \\
\cline { 2 - 5 } & Change & $\mathbf{0}$ & $\mathbf{- 1}$ & $\mathbf{- 1}$ \\
\hline \hline \multirow{3}{*}{ VI } & Nov. 9, 2020 & 70 & -445 & -375 \\
& Nov. 10, 2020 & 70 & -446 & $\mathbf{- 3 7 6}$ \\
\cline { 2 - 5 } & Change & $\mathbf{0}$ & $\mathbf{0}$ & $\mathbf{0}$ \\
\hline \hline \multirow{3}{*}{ VII } & Dec. 4, 2020 & 65 & -458 & -393 \\
\cline { 2 - 5 } & Dec. 7, 2020 & 64 & -459 & $\mathbf{- 3 9 5}$ \\
\cline { 2 - 5 } & Change & $\mathbf{- 1}$ & $\mathbf{- 2}$ & $\mathbf{- 2}$ \\
\hline
\end{tabular}

Table 10: Decomposition of One-Day Responses of the Ten-Year BEI to Announcements of Fiscal Measures

The decomposition of one-day responses of the Japanese ten-year BEI on seven fiscal policy announcement dates into changes in (i) the ten-year expected inflation and (ii) the ten-year inflation risk premium (IRP) based on the $G^{J}(4)$ model estimated with daily data and including the Consensus Forecasts of ten-year CPI inflation. All numbers æare measured in basis points. 


\begin{tabular}{|c|c|c|}
\hline No. & Date & Announcement description \\
\hline $\mathrm{I}$ & Apr. 8, 2020 & $\begin{array}{l}\text { The government issues state of emergency declaration until May } 6 \text { for } \\
7 \text { prefectures (Tokyo, Kanagawa, Chiba, Saitama, Osaka, Hyogo and } \\
\text { Fukuoka). }\end{array}$ \\
\hline II & Apr. 16,2020 & The state of emergency expanded nationwide. \\
\hline III & May 14,2020 & The state of emergency lifted, except for 8 large prefectures. \\
\hline IV & May 21,2020 & The state of emergency lifted in Osaka, Kyoto, and Hyogo. \\
\hline $\mathrm{V}$ & May 27, 2020 & $\begin{array}{l}\text { The state of emergency lifted in Hokkaido, Saitama, Chiba, Tokyo } \\
\text { and Kanagawa. }\end{array}$ \\
\hline
\end{tabular}

Table 11: Key COVID-19 Shutdown Announcements

\subsection{Responses to COVID-19 Shutdowns}

Finally, to put the registered responses to monetary and fiscal policy changes into perspective, we also examine the responses of the government bond market to news about shutdowns in Japan imposed to prevent the spread of the coronavirus. We consider five events associated with shutdowns or lifting thereof in response to developments in the pandemic, as shown in Table 11. These include the emergency declaration on April 8, 2020, for seven large prefectures; the nationwide shutdown that followed on April 16, 2020; the lifting of shutdowns for all but eight prefectures on May 14, 2020; the lifting of shutdowns for Osaka, Kyoto, and Hyogo on May 21, 2020; and the lifting of shutdowns for Hokkaido, Saitama, Chiba, Tokyo, and Kanagawa on May 27, 2020.

Table 12 reports the daily changes in BEI rates around the five COVID-related announcements concerning restrictions of activities. These events all resulted in modest one-day declines in the ten-year BEI, by between 1 and 4 basis points in absolute value once we account for the value of the deflation protection offered by the inflation-indexed bonds. As reported in Table 13, changes in long-term inflation expectations from our BEI decompositions moved even less, only falling one basis point for the two shutdown announcements and the announcement of the lifting of restrictions in all but eight prefectures on May 14.

We also again observe the impact of the deflation protection option. There is again, for example, a discrepancy by four basis points between the measured ten-year BEI without and with the deflation protection adjustment on the dates of the events of April 8 and May 14, and without the inflation protection adjustment we find no measurable impact of any event on ten-year expected inflation.

To summarize, the active monetary and fiscal responses announced in Japan to counter the severe economic shock caused by the spread of the COVID-19 pandemic also failed to give rise to any particularly noteworthy changes in BEI rates. In particular, our estimated changes in expectations on days of both types of expansion announcements were modest and 


\begin{tabular}{|c|c|c|c|c|c|c|}
\hline \multirow{2}{*}{\multicolumn{2}{|c|}{ Event }} & \multicolumn{5}{|c|}{ Fitted BEI } \\
\hline & & 1-year & 2-year & 5-year & 7 -year & 10-year \\
\hline \multirow{3}{*}{ I } & Apr. 7, 2020 & -26.9 & -26.4 & -22.4 & -18.9 & -13.3 \\
\hline & Apr. 8, 2020 & -27.6 & -27.1 & -23.0 & -19.4 & -13.8 \\
\hline & Change & -0.7 & -0.6 & -0.5 & -0.5 & -0.5 \\
\hline \multirow{3}{*}{ II } & Apr. 15, 2020 & -28.7 & -29.0 & -26.1 & -23.0 & -17.5 \\
\hline & Apr. 16, 2020 & -27.5 & -28.1 & -25.8 & -22.7 & -17.4 \\
\hline & Change & 1.2 & 0.9 & 0.4 & 0.2 & 0.1 \\
\hline \multirow{3}{*}{ III } & May 13,2020 & -15.7 & -17.7 & -17.4 & -15.1 & -10.3 \\
\hline & May 14,2020 & -15.0 & -16.9 & -16.7 & -14.3 & -9.5 \\
\hline & Change & 0.7 & 0.7 & 0.8 & 0.8 & 0.8 \\
\hline \multirow{3}{*}{ IV } & May 20, 2020 & -16.2 & -17.9 & -17.1 & -14.6 & -9.6 \\
\hline & May 21,2020 & -19.0 & -20.3 & -19.0 & -16.3 & -11.2 \\
\hline & Change & -2.8 & -2.5 & -1.9 & -1.7 & -1.5 \\
\hline \multirow{3}{*}{$\mathrm{V}$} & May 26, 2021 & -18.4 & -20.6 & -20.7 & -18.4 & -13.7 \\
\hline & May 27,2021 & -17.5 & -19.9 & -20.4 & -18.2 & -13.6 \\
\hline & Change & 0.9 & 0.7 & 0.3 & 0.2 & 0.0 \\
\hline \multirow{2}{*}{\multicolumn{2}{|c|}{ Event }} & \multicolumn{5}{|c|}{ Option-Adjusted BEI } \\
\hline & & 1-year & 2-year & 5-year & 7-year & 10-year \\
\hline \multirow{3}{*}{$\mathrm{I}$} & Apr. 7, 2020 & -3.5 & -76.9 & -208.4 & -254.5 & -293.7 \\
\hline & Apr. 8, 2020 & -8.7 & -81.7 & -212.6 & -258.5 & -297.4 \\
\hline & Change & -5.2 & -4.9 & -4.3 & -4.0 & -3.8 \\
\hline \multirow{3}{*}{ II } & Apr. 15, 2020 & -36.4 & -107.4 & -234.3 & -278.6 & -316.0 \\
\hline & Apr. 16, 2020 & -40.7 & -111.4 & -237.7 & -281.8 & -318.9 \\
\hline & Change & -4.3 & -4.0 & -3.4 & -3.1 & -2.9 \\
\hline \multirow{3}{*}{ III } & May 13,2020 & -87.8 & -155.0 & -274.9 & -316.4 & -351.2 \\
\hline & May 14,2020 & -92.2 & -159.0 & -278.2 & -319.4 & -353.9 \\
\hline & Change & -4.4 & -4.0 & -3.3 & -3.0 & -2.8 \\
\hline \multirow{3}{*}{ IV } & May 20, 2020 & -106.3 & -171.7 & -288.2 & -328.6 & -362.2 \\
\hline & May 21,2020 & -107.7 & -172.9 & -289.2 & -329.5 & -363.1 \\
\hline & Change & -1.4 & -1.3 & -1.0 & -0.9 & -0.8 \\
\hline \multirow{3}{*}{$\mathrm{V}$} & May 26, 2021 & -114.0 & -178.7 & $\begin{array}{l}-293.8 \\
\end{array}$ & -333.7 & -366.9 \\
\hline & May 27,2021 & -116.1 & -180.6 & -295.4 & -335.1 & -368.2 \\
\hline & Change & -2.1 & -1.9 & -1.6 & -1.4 & -1.3 \\
\hline
\end{tabular}

Table 12: One-Day Responses of Japanese BEI to COVID-19 Shutdown Announcements

The table reports the one-day response of Japanese BEI at five different maturities around five dates with COVID-19 related announcements. All numbers are measured in basis points. 


\begin{tabular}{|c|l|c|c||c|}
\hline \multicolumn{3}{|l|}{ Decomposition from $G^{J}(4)$ model without option adjustment } \\
\hline \hline \multirow{2}{*}{ Event } & $\begin{array}{c}\text { Ten-year exp. } \\
\text { inflation }\end{array}$ & $\begin{array}{c}\text { Ten-year } \\
\text { IRP }\end{array}$ & $\begin{array}{c}\text { Ten-year } \\
\text { BEI }\end{array}$ \\
\hline \hline \multirow{3}{*}{ I } & Apr. 7, 2020 & 83 & -96 & -13 \\
& Apr. 8, 2020 & 82 & -96 & -14 \\
\cline { 2 - 5 } & Change & $\mathbf{0}$ & $\mathbf{0}$ & $\mathbf{0}$ \\
\hline \hline \multirow{3}{*}{ II } & Apr. 15, 2020 & 83 & -100 & -17 \\
& Apr. 16, 2020 & 83 & -100 & -17 \\
\cline { 2 - 5 } & Change & $\mathbf{0}$ & $\mathbf{0}$ & $\mathbf{0}$ \\
\hline \hline \multirow{3}{*}{ III } & May 13, 2020 & 85 & -95 & -10 \\
& May 14, 2020 & 85 & -95 & -9 \\
\cline { 2 - 5 } & Change & $\mathbf{0}$ & $\mathbf{1}$ & $\mathbf{1}$ \\
\hline \hline \multirow{3}{*}{ IV } & May 20, 2020 & 85 & -95 & -10 \\
& May 21, 2020 & 85 & -96 & -11 \\
\cline { 2 - 5 } & Change & $\mathbf{0}$ & $\mathbf{- 1}$ & $\mathbf{- 2}$ \\
\hline \hline \multirow{3}{*}{ V } & May 26, 2020 & 85 & -98 & -14 \\
& May 27, 2020 & 85 & -98 & -14 \\
\cline { 2 - 5 } & Change & $\mathbf{0}$ & $\mathbf{0}$ & $\mathbf{0}$ \\
\hline
\end{tabular}

\begin{tabular}{|c|l|c|c||c|}
\hline \multicolumn{2}{|c|}{ Decomposition from $G^{J}(4)$ model with option adjustment } \\
\hline \hline \multirow{2}{*}{ Event } & $\begin{array}{c}\text { Ten-year exp. } \\
\text { inflation }\end{array}$ & $\begin{array}{c}\text { Ten-year } \\
\text { IRP }\end{array}$ & $\begin{array}{c}\text { Ten-year } \\
\text { BEI }\end{array}$ \\
\hline \hline \multirow{3}{*}{ I } & Apr. 7, 2020 & 86 & -380 & -294 \\
& Apr. 8, 2020 & 85 & -383 & -297 \\
\cline { 2 - 5 } & Change & $\mathbf{- 1}$ & $\mathbf{- 3}$ & $\mathbf{- 4}$ \\
\hline \hline \multirow{3}{*}{ II } & Apr. 15, 2020 & 81 & -397 & -316 \\
& Apr. 16, 2020 & 81 & -400 & -319 \\
\cline { 2 - 5 } & Change & $\mathbf{- 1}$ & $\mathbf{- 2}$ & $\mathbf{- 3}$ \\
\hline \hline \multirow{3}{*}{ III } & May 13, 2020 & 73 & -425 & -351 \\
& May 14, 2020 & 73 & -427 & -354 \\
\cline { 2 - 5 } & Change & $\mathbf{- 1}$ & $\mathbf{- 2}$ & $\mathbf{- 3}$ \\
\hline \hline \multirow{3}{*}{ IV } & May 20, 2020 & 70 & -432 & -362 \\
& May 21, 2020 & 70 & -433 & -363 \\
\cline { 2 - 5 } & Change & $\mathbf{0}$ & $\mathbf{- 1}$ & $\mathbf{- 1}$ \\
\hline \hline \multirow{3}{*}{ V } & May 26, 2020 & 69 & -436 & -367 \\
\cline { 2 - 5 } & May 27, 2020 & 68 & -437 & -368 \\
\cline { 2 - 5 } & Change & $\mathbf{0}$ & $\mathbf{- 1}$ & $\mathbf{- 1}$ \\
\hline
\end{tabular}

Table 13: Decomposition of One-Day Responses of the Ten-Year BEI to COVID19 Shutdown Announcements

The decomposition of one-day responses of the Japanese ten-year BEI on five dates with COVID-19 related announcements into changes in (i) the ten-year expected inflation and (ii) the ten-year inflation risk premium (IRP) based on the $G^{J}(4)$ model estimated with daily data and including the Consensus Forecasts of ten-year CPI inflation. All numbers are measured in basis points. 
similar to those observed on days when lockdown restrictions or their lifting were announced. As a consequence, we do not see reasons to be particularly optimistic about the ability of fiscal or monetary expansions to lift long-term inflation expectations when they are anchored at undesirably low levels.

\section{Conclusion}

This paper uses an arbitrage-free term structure model of nominal and real yields on Japanese government bonds to evaluate the impact on long-term inflation expectations of news concerning monetary and fiscal policy responses to the COVID-19 virus. As the virus was an exogenous shock, triggering monetary and fiscal policy responses, the episode is conducive to the study of the impact of expansionary monetary and fiscal policies. As a method of comparison, we also examine the implications of five announcements concerning the imposition or lifting of restrictions on activity in response to developments of the pandemic in Japan.

Our analysis accounts for deflation protection enhancements embedded in recently-issued inflation-indexed bonds. Due to Japan's persistently low, and frequently even negative, inflation experience. Our estimated value of these enhancements are typically large, ranging from 50-100 basis points to as high as 550 basis points following the pandemic. Moreover, they are volatile, suggesting that their incorporation would also be influential in the determination of the impacts of policy reforms.

Our results demonstrate that the onset of the virus resulted in further deterioration of Japanese ten-year inflation expectations, as from 2020 through 2021 ten-year inflation expectations slowly drifted towards zero. We also find that changes in long-term inflation expectations in Japan on both monetary and fiscal policy announcement dates, as well as changes in restrictions on activity, were very modest. Changes in both the ten-year BEI and inflation expectation estimates were universally small, and often negative, indicating that the primary initial implications of expansionary policy responses may have been to deepen pessimism about the prospects for recovery from the pandemic.

As a whole, these results indicate that Japanese long-term inflation expectations were largely unresponsive to both monetary and fiscal policy efforts, as well as policies based on imposing or easing restrictions on activity in response to the pandemic. As such, our results

illustrate the difficulty of raising long-term inflation expectations once those expectations are well-anchored below the announced monetary policy target. 


\section{References}

Abrahams, Michael, Tobias Adrian, Richard K. Crump, Emanuel Moench, and Rui Yu, 2016, "Decomposing Real and Nominal Yield Curves," Journal of Monetary Economics, Vol. $84,182-200$.

Andreasen, Martin M., Jens H. E. Christensen, and Glenn D. Rudebusch, 2019, "Term Structure Analysis with Big Data: One-Step Estimation Using Bond Prices," Journal of Econometrics, Vol. 212, 26-46.

Bauer, Michael D. and Glenn D. Rudebusch, 2014, "The Signaling Channel for Federal Reserve Bond Purchases," International Journal of Central Banking, Vol. 10, No. 3, 233-289.

Bauer, Michael D., Glenn D. Rudebusch, and Jing (Cynthia) Wu, 2012, "Correcting Estimation Bias in Dynamic Term Structure Models," Journal of Business and Economic Statistics, Vol. 30, No. 3, 454-467.

Bernhardt, Robert, Stefania D'Amico, and Santiago I. Sordo Palacios, 2022, "The Impact of Covid-19 Related Policy Responses on Municipal Debt Markets," Federal Reserve Bank of Chicago Working Paper No. 2021-14.

Bianchi-Vimercati, Riccardo, Martin S. Eichenbaum, and Joao Guerreiro, 2021, "Fiscal Policy at the Zero Lower Bound Without Rational Expectations," NBER Working Paper 29134, August 2021.

Boubaker, Sabri, Duc Khuong Nguyen, and Nikos Paltalidis, 2018, "Fiscal Policy Interventions at the Zero Lower Bound," Journal of Economic Dynamics and Control, Vol. 93, 297-314.

Chernov, Mikhail and Philippe Mueller, 2012, "The Term Structure of Inflation Expectations," Journal of Financial Economics, Vol. 106, No. 2, 367-394.

Christensen, Jens H. E., Francis X. Diebold, and Glenn D. Rudebusch, 2011, "The Affine Arbitrage-Free Class of Nelson-Siegel Term Structure Models," Journal of Econometrics, Vol. 164, No. 1, 4-20.

Christensen, Jens H. E. and Signe Krogstrup, 2019, "Transmission of Quantitative Easing: The Role of Central Bank Reserves," Economic Journal, Vol. 129, 249-272.

Christensen, Jens H. E., Jose A. Lopez, and Glenn D. Rudebusch, 2010, "Inflation Expectations and Risk Premiums in an Arbitrage-Free Model of Nominal and Real Bond Yields," Journal of Money, Credit and Banking, Supplement to Vol. 42, No. 6, 143-178. 
Christensen, Jens H. E., Jose A. Lopez, and Glenn D. Rudebusch, 2012, "Extracting Deflation Probability Forecasts from Treasury Yields," International Journal of Central Banking, Vol. 8, No. 4, 21-60.

Christensen, Jens H. E. and Glenn D. Rudebusch, 2012, "The Response of Interest Rates to U.S. and U.K. Quantitative Easing," Economic Journal, Vol. 122, F385-F414.

Christensen, Jens H. E. and Glenn D. Rudebusch, 2015, "Estimating Shadow-Rate Term Structure Models with Near-Zero Yields," Journal of Financial Econometrics, Vol. 13, No. 2, 226-259.

Christensen, Jens H. E. and Mark M. Spiegel, 2021, "Monetary Reforms and Inflation Expectations in Japan: Evidence from Inflation-Indexed Bonds," forthcoming Journal of Econometrics.

D'Amico, Stefania, Don H. Kim, and Min Wei, 2018, "Tips from TIPS: The Informational Content of Treasury Inflation-Protected Security Prices," Journal of Financial and Quantitative Analysis, Vol. 53, No. 1, 243-268.

Dooley, Ben and Eimi Yamamitsu, 2020, “Japan's Economy Shrank Sharply. Now Comes the Coronavirus," New York Times, February 19, https://www.nytimes.com/2020/02/16/business/coronavirus japan-economy.html.

Duffee, Gregory R., 2002, "Term Premia and Interest Rate Forecasts in Affine Models," Journal of Finance, Vol. 57, No. 1, 405-443.

Ehrmann, Michael, 2015, "Targeting Inflation from Below: How Do Inflation Expectations Behave?," International Journal of Central banking, Vol. 11, No. 4, 213-249.

Finlay, Richard and Sebastian Wende, 2012, "Estimating Inflation Expectations with a Limited Number of Inflation-Indexed Bonds," International Journal of Central Banking, Vol. 8, No. 2, 111-142.

Gagnon, Joseph, Matthew Raskin, Julie Remache, and Brian Sack, 2011, "Large-Scale Asset Purchases by the Federal Reserve: Did They Work?," International Journal of Central Banking, Vol. 7, No. 1, 3-43.

Goodfriend, Marvin, 2007, "How the World Achieved Consensus on Monetary Policy," Journal of Economic Perspectives, Vol. 21, No. 4, Fall, 47-68.

Gornostay, Egor and Madi Sarsenbayev, 2021, "Overheating Debate - Why Not in Japan?," Policy Brief 21-12, the Peterson Institute of International Economics, June 2021.

Grishchenko, Olesya V. and Jing-Zhi Huang, 2013, "Inflation Risk Premium: Evidence from the TIPS Market," Journal of Fixed Income, Vol. 22, No. 4, 5-30. 
Joslin, Scott, Kenneth Singleton, and Haoxiang Zhu, 2011, "A New Perspective on Gaussian Dynamic Term Structure Models," Review of Financial Studies, Vol. 24, No. 3, 926-970.

Kihara, Leika and Tetsushi Kajimoto, 2020, "Japan Unveils $\$ 708$ Billion in Fresh Stimulus with Eye on Post-COVID Growth," Reuters, December 7, https://www.reuters.com/article/usjapan-economy-stimulus/japan-unveils-708-billion-in-fresh-stimulus-with-eye-on-post-covidgrowth-idUSKBN28I02Y.

Kim, Don H. and Athanasios Orphanides, 2012, "Term Structure Estimation with Survey Data on Interest Rate Forecasts," Journal of Financial and Quantitative Analysis, Vol. 47, No. 1, 241-272.

Kim, Don H. and Kenneth J. Singleton, 2012, "Term Structure Models and the Zero Bound: An Empirical Investigation of Japanese Yields," Journal of Econometrics, Vol. 170, No. $1,32-49$.

KPMG, 2020, "Japan: Government and Institution Measures in Response to COVID-19," KPMG Insights, December 2, https://home.kpmg/xx/en/home/insights/2020/04/japangovernment-and-institution-measures-in-response-to-covid.html.

Kurosaki, Tetsuo, Yusuke Kumano, Kota Okabe, and Teppei Nagano, 2015, "Liquidity in JGB Markets: An Evaluation from Transaction Data," Bank of Japan Working Paper Series No. 15-E-2.

Kyodo News, 2020, "Japan Adopts 1 Tril. Yen Level Fresh Package to Fight Coronavirus," Kyodo News, March 10, https://english.kyodonews.net/news/2020/03/a313cff1eb57cabinet-oks-bill-to-enable-abe-to-declare-emergency-amid-virus-spread.html

Nelson, Charles R. and Andrew F. Siegel, 1987, "Parsimonious Modeling of Yield Curves," Journal of Business, Vol. 60, No. 4, 473-489.

Prime Minister of Japan and His Cabinet, 2020, "Ongoing Topics: Emergency Economic Measures for Response to COVID-19 to Protect the Lives and Lifestyles of the Public and Move Toward Economic Recovery," April 20, https://japan.kantei.go.jp/ongoingtopics/_00019.html.

Ramey, Valerie A. and Sarah Zubairy, 2018, "Government Spending Multipliers in Good and in Bad: Evidence from US Historical Data," Journal of Political Economy, Vol. 126, No. 2, 850-901.

Rudebusch, Glenn D. and Eric Swanson, 2012, "The Bond Premium in a DSGE Model with Long-Run Real and Nominal Risks," American Economic Journals: Macroeconomics, Vol. 4, No. 1, 105-43. 
Sakiyama, Toshiyuki and Shun Kobayashi, 2018, "Liquidity in the JGB Cash Market: An Evaluation from Detailed Transaction Data," Bank of Japan Reports and Research Papers, March 2018.

Takemoto, Yoshifumi and Daniel Leussink, 2020, "Japan PM Suga Instructs Cabinet to Compile New Stimulus Package," Reuters, November 9, https://www.reuters.com/article/usjapan-economy-stimulus/japan-pm-suga-instructs-cabinet-to-compile-new-stimulus-packageidUSKBN27Q066.

Takeo, Yuko, Yoshiaki Nohara, and Bloomberg, 2020, "Japan Launches $\$ 1$ Trillion Coronavirus Stimulus Package as Prime Minister Abe Announces State of Emergency," Fortune, April 6, https://fortune.com/2020/04/06/japan-coronavirus-stimulus-package-shinzoabe-state-of-emergency/

Yoshino, Naoyuki, Farhad Taghizadeh-Hesary, and Hiroaki Miyamoto, 2017, "The eEffectiveness of Japan's Negative Interest Rate Policy," ADBI Working Paper Series, No. 652, January 2017. 